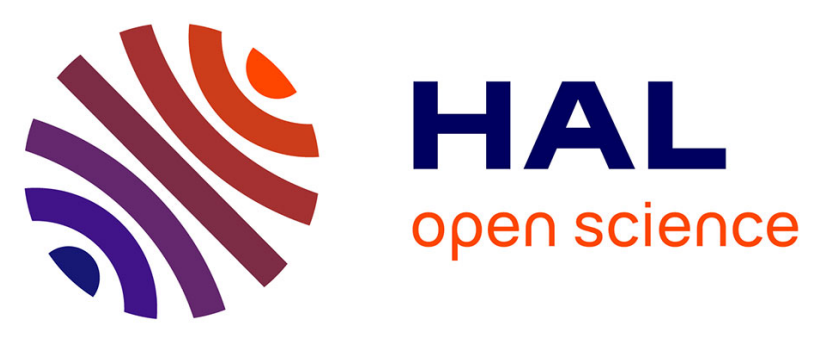

\title{
What can be learned from natural analogue studies in view of CO2 leakage issues in Carbon Capture and Storage applications? Geochemical case study of Sainte-Marguerite area (French Massif Central)
}

Frédérick Gal, Michel Brach, Gilles Braibant, Claire Bény, Karine Michel

\section{To cite this version:}

Frédérick Gal, Michel Brach, Gilles Braibant, Claire Bény, Karine Michel. What can be learned from natural analogue studies in view of $\mathrm{CO} 2$ leakage issues in Carbon Capture and Storage applications? Geochemical case study of Sainte-Marguerite area (French Massif Central). International Journal of Greenhouse Gas Control, 2012, 10, pp.470-485. 10.1016/j.ijggc.2012.07.015 hal-00723404

\section{HAL Id: hal-00723404 https: / hal-brgm.archives-ouvertes.fr/hal-00723404}

Submitted on 9 Aug 2012

HAL is a multi-disciplinary open access archive for the deposit and dissemination of scientific research documents, whether they are published or not. The documents may come from teaching and research institutions in France or abroad, or from public or private research centers.
L'archive ouverte pluridisciplinaire HAL, est destinée au dépôt et à la diffusion de documents scientifiques de niveau recherche, publiés ou non, émanant des établissements d'enseignement et de recherche français ou étrangers, des laboratoires publics ou privés. 
1 What can be learned from natural analogues studies in view of $\mathrm{CO}_{2}$ leakage issues in

2 Carbon Capture and Storage applications? Geochemical case study of Sainte-

3 Marguerite area (French Massif Central).

4

5 GAL Frédérick, BRACH Michel, BRAIBANT Gilles, MICHEL Karine, BENY Claire 6

$7 \quad$ BRGM (Bureau de Recherches Géologiques et Minières)

8 Metrology, Monitoring and Analyses Division

93 Avenue C. Guillemin

$10 \quad$ BP36009

1145060 Orléans cedex 1, France

12

13 Phone : + $33(0) 238643886$

14 Fax: + $33(0) 238643711$

15

16 E-mail : f.gal@brgm.fr

17 


\section{$\underline{\text { Abstract }}$}

19 Natural analogues studies have received much interest over past years through the $\mathrm{CO}_{2}$ capture and storage applications. In this paper we focus on one natural analogue in leakage situation in order to describe the nature of the gas leakage, its interaction with surrounding rocks and aquifers and its behaviour over time. Soil gas and water monitoring techniques are used to gather point and continuous records. Leakage occurs along discrete sections relying on the nature of surface formations and the permeability of discontinuities. Main gas vents are perennial, relative proportions of different gas phases $\left(\mathrm{CO}_{2},{ }^{222} \mathrm{Rn}\right.$ and $\left.{ }^{4} \mathrm{He}\right)$ being dependent from the interaction with surface deposits and the distance to main tectonic pathways.

Mineral waters were also monitored as they represent integrative bodies that exist above nearly all CCS sites. Constraints on chemical processes occurring at depth are brought by characterisation of the dissolved constituents and by related isotopic systematics. Such determination of mixing processes and their influence is important, as leakage from CCS site may be evidenced through the mixing of the water from the storage complex and overlying aquifers. Longer term monitoring was conducted for physico-chemical parameters highlighting noticeable variations for $\mathrm{pH}$, dissolved oxygen, redox potential and dissolved $\mathrm{CO}_{2}$.

\section{$\underline{\text { Keywords }}$}

Natural analogue

Carbon Capture and Storage

Soil gas monitoring

Water monitoring 


\section{Introduction}

43 Natural analogues studies have received much interest over past years through the prism of $\mathrm{CO}_{2}$ capture and storage (CCS) applications. Several references on this topic may be found in very recent papers such as e.g. Schütze et al. (2012). Natural analogues can either be in steady state conditions, i.e. in a non-leaking state, or at the opposite they can experience more or less developed leakages. In this paper we choose to focus on this second situation in order to evaluate how valuable information may be learnt from natural $\mathrm{CO}_{2}$ leakages and extrapolated to CCS sites. In this particular case of leaking analogues, features devoted to the study of storage integrity are by definition unrealistic. Nevertheless, such analogues represent a good opportunity to illustrate what must be avoided for CCS sites (Bachu, 2003).

Even if vertical gas flows are often much greater than those expected in case of undesired $\mathrm{CO}_{2}$ leakage from CCS site, natural analogues provide the opportunity to study the nature of a gas leakage, its interaction with surrounding rocks and aquifers, its behaviour over time or its potential impacts on surface environments (Lewicki et al., 2007). Consequently, natural analogues monitoring is an appropriate way to study natural seepages and is from the authors' point of view complementary with induced leak experiments such as the ZERT (Spangler, 2010) or the CO2FieldLab ones (http://www.sintef.no/Projectweb/co2fieldlab/).

The Sainte-Marguerite site allows the study of both $\mathrm{CO}_{2}$ leakage in shallow aquifers and gas escapes in near surface environments. Apart from pressure and temperature consideration, leakage in aquifers is the most critical parameter to assess for ensuring of CCS sites integrity. One must be confident with near surface monitoring technologies prior to use them in deeper environments. Second, monitoring of $\mathrm{CO}_{2}$ escapes as a gas phase may consist in the ultimate warner prior to leakage in the atmosphere. Health and risk assessment and public acceptance directly rely on those two aspects. 
Another interesting parameter to evaluate is the behaviour of natural analogues over long time periods. $\mathrm{CO}_{2}$ injection is a very recent process compared to timescale of geological processes. Consequently, apart from failures linked to defective constraint of a CCS site (leakage due to abandoned wells, existence of fractures or leakage through the caprock; Lemieux, 2011), leakage may occur at low rate over years and may not be highlighted by monitoring technologies at depth, especially geochemical ones that rely on discrete measurements. A better understanding of how the gas migrates from depth and how it imprints surface environments is a challenging question that may be addressed by studying naturally leaking sites. Defining the origin of the gas phase is an important issue in case of leakage at a CCS site, helping to decipher whether the gas originates from the reservoir itself or from other sources that do not involve CCS processes (e.g. Gilfillan et al., 2011).

The Sainte-Marguerite area belongs to the French Massif Central and more precisely to the southern part of the Limagne d'Allier basin (Figure 1). This tertiary basin is mainly filled by limestones with frequent sandy-clayey intercalations that are contemporary of the Oligocene to Miocene West European rifting. Alluvial and colluvial deposits from the Allier River partly overlie these tertiary strata and from place to place volcanic series crosscut the sedimentary formations. Mineral waters emerging in the Limagne d'Allier basin are strongly influenced by their deep circulation in the crystalline basement and the occurrence of deep $\mathrm{CO}_{2}$ sources (Fouillac, 1983). The main tectonic structures, inherited from the Hercynian orogeny, are respectively N10-N30 and N110-N130 (Merle and Michon, 2001). The Sainte-Marguerite area is also characterised by the presence of travertine deposits formed from water degassing at springs (Casanova et al., 1999; Fouillac, 1983; Rihs et al., 2000).

While studies on mineral waters - mostly of sodium bicarbonate type with $\mathrm{CO}_{2}$ present as a gas phase - from the Allier River valley are numerous (e.g. Négrel et al., 1997a and 
100

101

102

103

104

references therein), initial investigations of soil gas composition in the Sainte-Marguerite area were performed during the 90 's to locate new boreholes for perpetuating the commercial exploitation of this water (Appora-Gnekindy, 1992; Baubron et al., 1992). Earlier measurements were made in the 70's on the west bank of the Allier River at the Saladis spring (Batard et al., 1978).

The objective of this study is therefore, in light of the work done in the 90's, to compare the similarities and differences of gas emanations separated by 20 years. Point measurements and longer records will be used to examine the relationships existing between the near surface compartment and deeper seated processes.

Figure 1

\section{Methods}

Two types of investigative methods were used: soil gas characterisation and description of water flows. Soil gas measurements were made using procedures and equipment identical to those described by the authors elsewhere (e.g. Battani et al., 2010; Gal and Gadalia, 2011). The monitoring methodology was based on the following:

- $\mathrm{CO}_{2}, \mathrm{O}_{2}$ and $\mathrm{CH}_{4}$ soil gas concentrations were directly quantified in the field using landfill gas analyser (LFG20 gas analyser, ADC Gas Analysis Limited, UK). Gas content was measured at $1 \mathrm{~m}$ depth in order to minimize the effect of atmospheric gases. $\mathrm{CO}_{2}$ and $\mathrm{CH}_{4}$ contents were determined by non-dispersive infrared absorption and $\mathrm{O}_{2}$ contents by electrochemistry. $\mathrm{No} \mathrm{CH}_{4}$ was found during the successive surveys indicating concentrations lesser than $0.01 \%$ volume in the gas phase. As the $\mathrm{CO}_{2}$ concentrations ranged from less than $1 \%$ up to $100 \%$, precision of the measurements 
varied between $\pm 0.5 \%$ of the reading for $\mathrm{CO}_{2}<10 \%$ to $\pm 5 \%$ of the reading for $\mathrm{CO}_{2}>$ $50 \%$.

${ }^{4} \mathrm{He}$ and ${ }^{222} \mathrm{Rn}$ concentrations were also systematically determined using samples collected in Tedlar bags for ${ }^{4} \mathrm{He}$ and vacuumed scintillating flasks for ${ }^{222} \mathrm{Rn}$, respectively. Concentrations were obtained using mass spectrometry for ${ }^{4} \mathrm{He}$ (Adixen ASM102S leak detector, France) and scintillation counting for ${ }^{222} \mathrm{Rn}$ (Calen, Algade, France). covered by a Goretex membrane and buried at $1 \mathrm{~m}$ depth in the ground.

The joint determination of these gaseous species allow to compare information from tracers that may be enriched through geothermal reservoir processes $\left({ }^{4} \mathrm{He}\right)$, from poorly mobile elements that may help highlight areas with significant gas fluxes $\left({ }^{222} \mathrm{Rn}\right)$ and from a widely existing gas $\left(\mathrm{CO}_{2}\right)$ that may be tracer of soil/atmosphere exchanges or of deep seated endogenic processes. Weather conditions were also taken into account for the interpretation of the soil gas data and will be discussed together with the data. 
139 Secondly, as the Sainte-Marguerite area is known for its mineral water resources, chemical

140 characterisation of some springs (physico-chemical parameters and dissolved ions content)

141 was also performed as well as the monitoring of the Brissac Geyser during several hours using

142 a multi-parameter Idronaut probe (Idro316Plus). Dissolved ion contents were determined at

143 laboratory using ICP-AES (Inductively Coupled Plasma - Atomic Emission Spectroscopy)

144 and chromatographic methods. Isotope ratios were measured by gas phase mass spectrometry

$145\left(\delta^{18} \mathrm{O}\right.$ and $\delta \mathrm{D}$ are expressed in \% VSMOW - Vienna Standard Mean Oceanic Water $)$. The

146 Idronaut probe was used to monitor the short-time evolution of temperature, $\mathrm{pH}$, specific

147 conductance, dissolved oxygen, redox potential and dissolved $\mathrm{CO}_{2}$ content of the water.

148

\section{3. Gas and water measurements}

$150 \quad 3.1$ Soil gas data

151 A dataset of nearly 1000 data points for each gas specie $\left(\mathrm{CO}_{2},{ }^{222} \mathrm{Rn}\right.$ and $\left.{ }^{4} \mathrm{He}\right)$ is available, 152 half of them from the 90's measurements and the rest from more recent measurements (Table $1531)$.

Table 1

$\mathrm{CO}_{2}$ concentrations range from values close to those of the atmosphere up to $100 \%$ vol. The

158 frequency distributions are different between the two measurement periods in relation to the 159 spatial arrangement of the measurements that is dictated by the tectonic and geological structure of the study area. As a consequence, the mean $\mathrm{CO}_{2}$ concentration is significantly greater for the 2006-2010 dataset than for the 1992 dataset.

Radon-222 $\left({ }^{222} \mathrm{Rn}\right)$ concentrations also fall within similar ranges during the two periods,

163 minimum values being close to $150 \mathrm{~Bq} \cdot \mathrm{m}^{-3}$ and greater ones around $2 \times 10^{6} \mathrm{~Bq} \cdot \mathrm{m}^{-3}$. The mean 
values were again higher for the 2006-2010 period as a consequence of data acquisition mainly focused on the Western part of the area. Nevertheless the variation of mean concentrations is only a factor of two whereas it was a factor of four for $\mathrm{CO}_{2}$ concentrations.

Helium-4 $\left({ }^{4} \mathrm{He}\right)$ concentrations are on average quite close to the atmospheric content but this value hides important differences. Both in 1992 and 2006-2010 some measurements showed very strong depletions when compared to the atmospheric content while others had strong enrichments $(\geq 10 \mathrm{ppm})$.

Most of the $\mathrm{CO}_{2}$ measurements made between 2006 and 2010 were also supplemented by measurements of the $\mathrm{O}_{2}$ concentrations in soils. A very homogeneous inverse behaviour exists between those species (Figure 2). Almost all data exhibit an $\mathrm{O}_{2}$ decrease that is not proportional with the increase of the $\mathrm{CO}_{2}$ content on a per mole basis. Depletion of $\mathrm{O}_{2}$ is much faster with a factor close to 5 . This suggests that $\mathrm{CO}_{2}$ is supplied in abundance by a powerful process probably related to a deep gas source (crustal and/or mantle origin) as will be discussed later.

Figure 2

This strong $\mathrm{O}_{2}$ depletion is also confirmed by the gas chromatography measurements reported in Figure 3. Correlations with other gas species follow linear regression with $\mathrm{r}^{2}$ between 0.991 and 0.998 , and also suggest a different behaviour between the $\mathrm{CO}_{2}$ end-member and the $\mathrm{N}_{2}$ $\mathrm{O}_{2}$-Ar triptych, with $\mathrm{CO}_{2}$ becoming predominant as the other three gases diminish and viceversa. This was particularly true for a $30 \mathrm{~m}$ deep borehole where atmospheric constituents were only detected at trace levels $\left(0.13 \% \mathrm{~N}_{2} ; 0.023 \% \mathrm{O}_{2} ; 0.002 \% \mathrm{Ar}\right)$. Using the relationship presented in Figure 3, it is then possible to recalculate an average composition for the 
atmospheric end-member. Ar and $\mathrm{N}_{2}$ contents were respectively at $0.932 \%$ and $79.6 \%$, levels that are very close to those usually reported for the atmosphere (respectively 0.934 and 78.08\%; http://encyclopedia.airliquide.com//). Unlike $\mathrm{O}_{2}$, which is subject to a more active kinetic of replacement, $\mathrm{N}_{2}$ and $\mathrm{Ar}$ are diluted in the soil gas by equimolar replacement with $\mathrm{CO}_{2}$

Figure 3

Finally, the $\delta^{13} \mathrm{C}$ isotope ratio of the $\mathrm{CO}_{2}$ gas was also evaluated on these samples and ranged between -3 to $-5.1 \%$ VPDB for $\mathrm{CO}_{2}$ in the $14-100 \%$ vol. range.

\section{$\underline{3.2 \text { Water measurements }}$}

The main physico-chemical properties of mineral springs sampled during the study are listed in Table 2. A rain event collected in October 2008 is also reported for comparison. The emergence temperatures range between 16 and $30^{\circ} \mathrm{C}$ and $\mathrm{pH}$ between 6.2 and 7.2 , therefore comparable to those reported by Négrel et al. (1997b) for the carbogaseous waters known throughout the French Massif Central. Specific conductances vary between 2.5 and 8.4 $\mathrm{mS} . \mathrm{cm}^{-1}$, Chapelle springs (used for bottling) having total mineralization approximately half of other sampled waters. The mineralization is dominated by $\mathrm{HCO}_{3}\left(1.3\right.$ to 4 g. $\left.\mathrm{L}^{-1}\right), \mathrm{Na}(0.3$ to 1.5 g. $\left.\mathrm{L}^{-1}\right)$ and $\mathrm{Cl}\left(0.2\right.$ to 1.5 g. $\left.\mathrm{L}^{-1}\right)$. If this $\mathrm{Na}-\mathrm{Cl}-\mathrm{HCO}_{3}$ facies predominates, the $\mathrm{Ca}$ and $\mathrm{Mg}$ amounts, less variable (respectively 120 to $310 \mathrm{mg} \cdot \mathrm{L}^{-1}$ and 100 to $140 \mathrm{mg} \cdot \mathrm{L}^{-1}$ ), allow the Chapelle springs - due to their lower dissolved elements concentrations - to be linked with the Ca-Mg pole, suggesting a secondary enrichment associated with the chemical hardness of bicarbonate-rich waters (Michard et al., 1981). Similarly, the Chapelle springs have an 
214 oxidizing character contrary to Tennis and Geyser Brissac waters that are characterized by a

215 marked reducing character. Characteristics of isotope ratios reported in Table 2 will be 216 discussed in section 5.

218 Table 2

\section{Interpretation of soil gas data}

\section{$\underline{4.1 \text { Point data }}$}

One of the first steps to considered for highlighting a potential leakage at a CCS site is to characterise the $\mathrm{CO}_{2}$ phase. Concentration measurements are of great interest but they may not be sufficient e.g. in case of small leakage rate. Additional information may be gathered using isotope systematics, mobile systems nowadays allowing on-site measurements (e.g.

Picarro or Aerodyne lasers). $\delta^{13} \mathrm{C}$ isotope ratio measurements will not give direct indication of the process that may be involved in the production of the $\mathrm{CO}_{2}$ phase but will allow 1) to discriminate between several origins and 2) to discard some unrealistic origins.

In the case of Sainte-Marguerite, $\mathrm{CO}_{2}$ concentrations in soils are supposed to evolve primarily under the influence of deep seated processes rather than surface processes. Indeed, the range of $\delta^{13} \mathrm{C}_{\mathrm{CO} 2}$ isotope ratios in soil gas (-3 to $-5.1 \%$ ) is related to deep crustal and/or mantle degassing (-4 to $-8 \%$; Gerlach and Taylor, 1990). Similarly, $\delta^{13} \mathrm{C}_{\mathrm{CO} 2}$ are close to ratios Central (-6.4\%o; Dégranges et al., 1978). The more depleted ratio (-5.1\%o) was measured in the $30 \mathrm{~m}$ borehole, where the gas phase was $100 \% \mathrm{CO}_{2}$ with no ${ }^{4} \mathrm{He}(<0.05 \mathrm{ppm})$, whereas soil gas measurements $(1 \mathrm{~m}$ depth) were slightly enriched in carbon-13 (i.e. greater than - 
239 complementary phenomena, first the percolation of $\mathrm{CO}_{2}$ through surface aquifers $\left(\delta^{13} \mathrm{C}\right.$ of 240 dissolved carbon from local springs close to 10.2\%; Mercier, 1987) and second the 241 interaction with travertine deposits $\left(\delta^{13} \mathrm{C}\right.$ between 5.4 and 7.7\% ; Casanova et al., 1999).

243 In the case of leakage originated from a CCS site, such characterisation using the only $\delta^{13} \mathrm{C}$ 244 isotope ratio will be much more difficult as overlaps between several gas origins and frequent 245 re-equilibration will certainly occur. A way to better constrain gas emanation is to measure 246 other gas species with different chemical properties.

247 In the present study we mainly refer to ${ }^{222} \mathrm{Rn}$ and ${ }^{4} \mathrm{He}$. As ${ }^{222} \mathrm{Rn}$ and ${ }^{4} \mathrm{He}$ are only present as 248 trace levels in the free atmosphere (respectively around 50 Bq.m ${ }^{-3}$ or less and $5.24 \mathrm{ppm}$ ), an 249 enrichment would favour the existence of phenomena occurring either in the soil or in the 250 upper regolith $\left({ }^{222} \mathrm{Rn}\right)$ or deeper in the ground ( ${ }^{4} \mathrm{He}$; Battani et al., 2010; Gilfillan et al., 2011). 251 Relationships between $\mathrm{CO}_{2},{ }^{222} \mathrm{Rn}$ and ${ }^{4} \mathrm{He}$ are presented in Figure 4.

Figure 4

255 For ${ }^{222} \mathrm{Rn} / \mathrm{CO}_{2}$ and ${ }^{4} \mathrm{He} / \mathrm{CO}_{2}$ couples, graphical relationships (Figure 4A) confirm the different 256 origin of these two gases and highlight that the genesis of ${ }^{4} \mathrm{He}$ from radioactive decay of 257 uranium in the near surface has little influence on the ${ }^{4} \mathrm{He}$ concentrations. This should also 258 result in an increase of the ${ }^{4} \mathrm{He}$ concentration when ${ }^{222} \mathrm{Rn}$ activities are high. This is not the 259 case, since there is rather a gradual depletion when the ${ }^{222} \mathrm{Rn}$ activities exceed $10^{6} \mathrm{~Bq} \cdot \mathrm{m}^{-3}$ 260 (Figure 4A). Moreover, these high ${ }^{222} \mathrm{Rn}$ concentrations are measured at precise locations 261 which correspond to surface discharges of springs (old factory and Tennis; Figure 1) that form 262 tens of centimetres to several meters thick travertine beds. These very high ${ }^{222} \mathrm{Rn}$ activities are 263 presumably related to these travertines, consequently richer in uranium than the alluvial 
264 formations and the local waters (Casanova et al., 1999). In this particular case, the $\mathrm{CO}_{2}$ source 265 is not strong enough to dilute the ${ }^{222} \mathrm{Rn}$ as may occur farther from travertine deposits. As a consequence, perennial ${ }^{222} \mathrm{Rn}$ high concentrations exist locally.

267 The behaviour of ${ }^{222} \mathrm{Rn}$ and $\mathrm{CO}_{2}$ is also complex for ${ }^{222} \mathrm{Rn}$ concentrations lesser than 300,000 268 Bq.m ${ }^{-3}$ (Figure 4B). Two distinct trends seem to exist, one with fast ${ }^{222} \mathrm{Rn}$ enrichment with 269 low $\mathrm{CO}_{2}$ concentrations (red squares), and the other with weaker ${ }^{222} \mathrm{Rn}$ enrichment when $\mathrm{CO}_{2}$ 270 concentrations rise (blue lozenges). These two behaviours correspond to various spatial 271 locations (Figure 5). Most of the "high ${ }^{222} \mathrm{Rn}-$ low $\mathrm{CO}_{2}$ " samples plot on the eastern part of 272 the site on sedimentary deposits (mean altitude 350 to $365 \mathrm{~m}$ ), whereas the majority of the 273 "low ${ }^{222} \mathrm{Rn}-$ high $\mathrm{CO}_{2}$ " group is restricted to a lower terrace of the Allier river (westward 274 from longitude 669,100 in Figure 5 - mean altitude 335 to 345 m; see also Battani et al., 2010 275 for geological cross-section). Near the Allier River, the thickness of geological formations overlying permeable paths is lesser than eastward. The $\mathrm{CO}_{2}$ gas interacts to a lesser extent 277 with surface formations, leading to moderate ${ }^{222} \mathrm{Rn}$ enrichment. On the contrary, on the 278 eastern part of the site, $\mathrm{CO}_{2}$ has to go through thicker formations (alluvial and Oligocene 279 formations), leading to smaller $\mathrm{CO}_{2}$ amounts and also to ${ }^{222} \mathrm{Rn}$ enrichment due to the 280 percolation of the $\mathrm{CO}_{2}$ into these formations. An intermediate behaviour occurs above 281 travertines deposits (Figures 4 and 5) where the ${ }^{222} \mathrm{Rn}$ content is also dependent from the 282 uranium content of these formations. An additional process can also act in a complementary 283 fashion. Deep $\mathrm{CO}_{2}$ may be less diluted on the western part of the site than on the eastern part, 284 indicating a more pronounced upward flow that allows the dilution of radon signal (Baubron, 285 1992; Gal et al., 2011).

286 No relationship can be highlighted for the ${ }^{4} \mathrm{He} / \mathrm{CO}_{2}$ couple except from a very weak tendency 287 of having slightly lower ${ }^{4} \mathrm{He}$ concentrations when $\mathrm{CO}_{2}$ concentration is greater than $50 \%$ 288 (Figure 4A). If considering the $30 \mathrm{~m}$ depth borehole as the most representative of the deep 
289

290

end-member, then uprising gas flow is ${ }^{4} \mathrm{He}$ depleted. A strong $\mathrm{CO}_{2}$ flux can act as a flushing agent on ${ }^{4} \mathrm{He}$. For lesser $\mathrm{CO}_{2}$ amounts, flushing effect may be less important and ${ }^{4} \mathrm{He}$ concentrations are higher or even enriched depending on the amounts of ${ }^{4} \mathrm{He}$ upward migrating.

\section{Figure 5}

The great variability of soil gas concentrations on a small area is not only dependent from deep processes but also from the heterogeneity of surface formations and pathways. Such a problematic is critical for CCS sites especially in areas where potential leakage pathways are not well characterised. This will raise the question on how detect surface leakage if e.g. a leakage occurred in deep groundwaters. Nevertheless, a positive point is the persistence of leakage structures over years.

As a result, the Sainte-Marguerite area presents a patchy repartition of anomalies at surface, as evidenced by the equal concentration lines reported on Figure 6. Data are interpolated using natural neighbour algorithm. This interpolation method is more rugged than e.g. kriging, but it has the advantage in not extrapolating the contours beyond the convex hull of the dataset. The whole dataset is presented top of Figure 6. Separate contributions from the data acquired during the 90 's and during the 2000's are respectively presented middle and bottom parts of Figure 6. A good match is highlighted between these 15-year interval datasets especially on the Western part of the study site where strong $\mathrm{CO}_{2}$ enrichments remain perennial. The match cannot be achieved for the Southern part as a new bottling facility has been built in between time therefore no measurement is yet possible. The North-South to N10 anomalous zone is well in agreement with structural directions reported in the Limagne d'Allier basin (Merle and Michon, 2001). This direction is also suggested by variogram 
314 computations (data not shown) which suggest, under a spherical model, a significant nugget 315 effect (40\% of the variability) and a reduced leg $(20 \mathrm{~m})$. Consequently, there seems to be at 316 site scale a structure directly related the Hercynian tectonic and at a smaller scale a less 317 obvious structure that is difficult to model even with a large amount of data.

318 For CCS site management, this suggests that once fed by seepage or microseepage, a leakage 319 pathway will remain active over a long time period. Its characterisation will then be possible 320 but remediation actions will be very difficult to undertake.

Figure 6

324 The complex $\mathrm{CO}_{2}$ distribution in soils is not restricted to this gas phase. A well characterised 325 time coherence for ${ }^{222} \mathrm{Rn}$ concentrations (90's and 2000's datasets) also exists and reveals an anomalous area close to the flow axis of the Allier river (Figures 2 and 6). A N170 direction is suggested by variogram calculations, with a leg identical to that defined for $\mathrm{CO}_{2}$ but with increased nugget effect ( $50 \%$ of the variability). This may be linked to the location of the area 329 of maximum ${ }^{222} \mathrm{Rn}$ concentrations, close to the high $\mathrm{CO}_{2}$ area but with no coinciding peaks, 330 and due to the difference of origin for these two gases, radon being preferentially produced in shallower environments than $\mathrm{CO}_{2}$ in the present case.

333 The evolution of ${ }^{4} \mathrm{He}$ concentrations in the area where ${ }^{222} \mathrm{Rn}$ and $\mathrm{CO}_{2}$ anomalies are located is 334 very interesting to detail (Figure 6). This area is characterized by a complex intricacy of 335 positive and negative anomalies in helium i.e. tracing enrichment or depletion with respect to 336 the atmospheric content. This complexity in ${ }^{4} \mathrm{He}$ emanations is remarkably stable over time. 337 Low ${ }^{4} \mathrm{He}$ concentrations are preferentially measured along a N10 axis, locally reinforced by a 
complementary N160 direction. The adjustment on a spherical model of the variogram suggests a maximum correlation distance of $40 \mathrm{~m}$ between two points without a nugget effect.

341 In order to better assess the behaviour of $\mathrm{CO}_{2},{ }^{222} \mathrm{Rn}$ and ${ }^{4} \mathrm{He}$, a linearization of the data was 342 made using the scheme proposed by Michel - Le Pierrès et al. (2010). The resulting 343 interpolation map is presented in Figure 7. By assumption, $\mathrm{CO}_{2}$ and ${ }^{4} \mathrm{He}$ are considered as 344 deep end-members and ${ }^{222} \mathrm{Rn}$ as a near surface produced gas. This is consistent with gas 345 origins suggested by Jeandel et al. (2010) that found a nearly half/half mantle/crust origin for 346 helium and a predominant crustal origin for $\mathrm{CO}_{2}$. This strengthens previous results indicating 347 that $\mathrm{CO}_{2}$ and ${ }^{4} \mathrm{He}$ amounts are not directly proportionally linked. The linearization process is 348 then intended to lower the influence of ${ }^{222} \mathrm{Rn}$ and to over-estimate the one of ${ }^{4} \mathrm{He}$ by assigning 349 a value between 0 and 1 to each of the gas specie. The 0.05 to $100 \% \mathrm{CO}_{2}$ range is restricted in 350 the $0-1$ interval and so on for ${ }^{222} \mathrm{Rn}\left(140\right.$ to 248,000 Bq.m $\left.{ }^{-3}\right)$ and ${ }^{4} \mathrm{He}(0.05$ to $9.83 \mathrm{ppm})$. 351 Using this procedure, ${ }^{4} \mathrm{He}$ concentrations account for c.a. $75 \%$ of the total variability, $\mathrm{CO}_{2}$ for 352 $22 \%$ and ${ }^{222} \mathrm{Rn}$ for the rest (c.a. 3\%). Despite this bias introduced in the dataset (Figure 7), the 353 surface geometry of the anomalies is still primarily guided by the distribution of $\mathrm{CO}_{2}$ 354 concentrations, the influence of ${ }^{4} \mathrm{He}$ been of second order. Consequently, it is the deep $\mathrm{CO}_{2}$ 355 source that governs the spatial distribution of anomalies in soil gas through the N10-N30 and N110-N130 structures (Merle and Michon, 2001). Other gaseous species evolve either 357 through the heterogeneous composition of the regolith or through the existence of complex 358 phenomena including convective transport, stripping or mixing. This strong imprint of 359 geological structures on the occurrence of anomalies also appears in the comparison of data acquired 15 years apart, since changes between these two periods remain small. This statement is strengthened by comparison with $\mathrm{CO}_{2}$ flux data available in the area (Battani et al., 2010). The most anomalous $\mathrm{CO}_{2}$ areas correspond to those marked by fluxes reaching or 
exceeding $500 \mathrm{~cm}^{3} \cdot \mathrm{min}^{-1} \cdot \mathrm{m}^{-2}$, while the radon anomalies are superimposed on areas where the

364 fluxes are smaller (lesser than $100 \mathrm{~cm}^{3} \cdot \mathrm{min}^{-1} \cdot \mathrm{m}^{-2}$ ).

Figure 7

\subsection{Time evolution of soil gas concentrations}

369 Evaluation of short-term variability of soil gas concentrations was evaluated using point 370 measurements $\left(\mathrm{CO}_{2},{ }^{222} \mathrm{Rn}\right.$ and ${ }^{4} \mathrm{He}$ ) and continuous measurements (on the $\mathrm{CO}_{2}$ phase using 371 Fourier Transform Infrared gas spectrometry). Repeated point measurements over 3 days 372 (points 1 to 4 in Figure 1) indicated that the points located northward of the site experienced 373 low variability of their gas concentrations $\left( \pm 60 \%\right.$ for $\left.\mathrm{CO}_{2}\right)$. At the opposite points located in 374 the southern part of the site had much greater variations rising up to a factor of 80 for $\mathrm{CO}_{2}$ and 375200 for ${ }^{222} \mathrm{Rn}$ (point 4). Continuous measurements in upper soil horizons in the vicinity of the 376 Brissac Geyser had an intermediate variation factor of 8 over few hours, with periodicity 377 influenced by the geyser own kinetic (mean period of 21 minutes).

378 Assessing the variability of gas emanations at short time scale is important for the 379 comprehension of phenomena occurring at a natural analogue, but such a time scale is not 380 fully matching requirements of CCS site monitoring. Longer chronicles shall be available in 381 order to highlight any deviation from environmental background noise. The Sainte-Marguerite 382 site has then been instrumented for longer-term measurements. They were performed only on 383 the ${ }^{222} \mathrm{Rn}$ phase for practical reasons. Even if deviations that may be recorded will not be 384 linked to deviations from an environmental background noise in the present case, one must be 385 confident in the capacity of monitoring devices to properly register unexpected events. 
Points 2 and 4 (Figure 1) were instrumented with Barasol probes from October 2008 to

387 January 2009 for hourly monitoring and afterwards only the point 4 remained. Soil 388 temperature and barometric pressure were simultaneously recorded at $1 \mathrm{~m}$ depth in the soil.

389 Meteorological data were got from an airport weather station located $14 \mathrm{~km}$ NNW from 390 Sainte-Marguerite, at similar altitude. Two distinct time responses exist (Figure 8):

- Pressures measured at $1 \mathrm{~m}$ depth in soils perfectly replicate the variations of atmospheric pressure and provide accurate description of local evolutions (Figure 8a);

- Temperatures measured in the soil are different from those measured in the atmosphere (Figure $8 \mathrm{~b}$ ). Soil temperatures exhibit a smoother daily variability and are higher than atmospheric temperatures. There is a time-lag between the maxima of temperature in the atmosphere and in the soil, the former occurring 5 to 6 hours before the later.

In December 2008 and January 2009, there is however a difference between temperatures

measured by the two probes (Figure $8 \mathrm{~b}$ ). The probe located in the southern part of the study area (point 4 in Figure 1) recorded higher temperatures (from 5 to $10^{\circ} \mathrm{C}$ ) than those measured 401 a few hundred meters northward (point 2 in Figure 1). Point 4 being located in a depression 402 close to mineral springs $\left(25\right.$ to $29^{\circ} \mathrm{C}$ at the orifice), this warming may be related to their 403 influence into higher groundwater level during winter times.

404

Figure 8

407 Radon activities measured by the 2 probes during the October 2008 - January 2009 period 408 showed trends with site-specific evolution but the variability of the measurement remained in 409 a similar range (Figure $8 \mathrm{c}$ ). There is a good agreement between average ${ }^{222} \mathrm{Rn}$ concentrations 410 computed from Barasol records (Table 3) and that from point measurements performed at site 
411 scale (Table 1). Marked activity peaks nevertheless occurred. At the end of January 2009

412 (Figure 8c), phenomenal concentrations were reached (up to $80 \times 10^{6}$ Bq.m $\mathrm{m}^{-3}$ ). Such 413 concentrations remain under saturation threshold of the probe $\left(10^{9} \mathrm{~Bq} \cdot \mathrm{m}^{-3}\right)$ but are far greater

414 than maximum values found during spot sampling $\left(2.5 \times 10^{6}\right.$ Bq.m $\left.{ }^{-3}\right)$. During this January 2009

415 event, a perfect synchronism was found between the 2 probes with a very quick increase

416 followed by very small ${ }^{222} \mathrm{Rn}$ amounts few hours later. This event is therefore not related to

417 malfunctioning of the equipment. The measurements suggest a gas burst sweeping the area of

418 Sainte-Marguerite, leading to a huge increase in ${ }^{222} \mathrm{Rn}$ and a subsequent strong depletion.

419 Concentrations remained low until radioactive decay produced again a sufficient amount of 420

${ }^{222} \mathrm{Rn}$. Another peak of activity was also detected in September 2009 (Figure 8c). However, as

421 only one sensor was deployed and as it experienced some operational problems, we prefer not

422 trying to interpret this latter signal.

423

424

Table 3

425

426

Apart from these specific periods, the ${ }^{222} \mathrm{Rn}$ concentrations change cyclically (Figure 8).

Cycle analysis returned variable results depending on the analysed time period and even on the location of the probe (Table 3). There was no clear influence of external forcing such as daily or diurnal variations over long time periods or the existence of pulsation of longer duration. It is therefore not possible to highlight regular gas emanations as may be possible

431 regionally such as in the vicinity of Lake Pavin (Gal and Gadalia, 2011).

432 Nevertheless, during periods characterised by less noisy ${ }^{222} \mathrm{Rn}$ signals (March 2009; Figure $4339 \mathrm{a}, \mathrm{b}$ and $\mathrm{c}$ ), a daily cyclicity (24 hours period) clearly appeared even if trends of greater 434 wavelength may also contribute to the shape of the recorded signal (Figure 9d). Principal 435 Component Analysis were calculated by combining the factors accounting for maximum 
436

437

438

439

440 441 bursts".

442

443

444

445

446

447

448

449

450

451

452

453

454

455

456

457

458

459

Figure 9

variability (Figures 9e and f). The only apparent trend was an inverse correlation between ${ }^{222} \mathrm{Rn}$ concentration and soil temperature. Given the interdependence between soil and atmospheric temperature, this trend can be extended to this second parameter. Thermal forcing seemed to be more efficient than pressure gradients to influence the short-term temporal evolution of ${ }^{222} \mathrm{Rn}$ concentrations, apart from sudden phenomena such as "gas

As previously described, the occurrence of large ${ }^{222} \mathrm{Rn}$ concentration peaks was very intriguing. The origin of such short pulses may typically be attributed to external causes such as earthquakes. Radon is frequently used as an indicator of crustal movement (precursor), although each earthquake does not raise an ${ }^{222} \mathrm{Rn}$ anomaly and each anomaly is not necessarily followed by an earthquake (e.g. Al-Hilal et al., 1998). According to dislocation model (Fleischer, 1981; Fleischer and Mogro-Campero, 1985), variations of ${ }^{222} \mathrm{Rn}$ concentrations issued from stress changes can be detected even at great distances from epicentres, involving a wide set of mechanisms (Kharatian et al., 2002). Continuous measurements of ${ }^{222} \mathrm{Rn}$ in soil gas sometimes allow the identification of spike-like anomalies just before the earthquake, the post-seismic stage being characterised by a rapid return to natural background values (Chyi et al., 2002). Although highly variable, increases in ${ }^{222} \mathrm{Rn}$ concentrations at $1 \mathrm{~m}$ depth in soils (Wattananikorn et al., 1998) often occur between 4 and 15 days before earthquakes of magnitude 2 to 6 with distances from the epicentre to the measuring station comprised between 15 to $250 \mathrm{~km}$ (Das et al., 2006; Ghosh et al., 2007; Ramola et al., 2008). 
Referring to these constraints, we searched the available databases (http://www-dase.cea.fr/)

461 for events reported in an area covering 4 degrees in longitude and 3 degrees in latitude, centered on Sainte-Marguerite. Twelve earthquakes were recorded between January 28 (12 463 hours after the ${ }^{222} \mathrm{Rn}$ peak) and February 13 (17 days after the ${ }^{222} \mathrm{Rn}$ peak) within this area, at 464 distances between 40 and $70 \mathrm{~km}$ from Sainte-Marguerite. All were characterised by very low 465 magnitudes less than 2.5. Although some of the cited literature reports a sensitivity of ${ }^{222} \mathrm{Rn}$ 466 measurements for low seismic magnitudes, no clear relationship exists in the present case 467 between ${ }^{222} \mathrm{Rn}$ peaks and tectonic activity.

468 Such excursions of ${ }^{222} \mathrm{Rn}$ signal were earlier reported on the Weyburn site, which is not 469 known to be tectonically active (Riding and Rochelle, 2009). Phenomena observed at 470 Weyburn were short (3 hours) and activities varied by factors of 7 to 15 . At Sainte-Marguerite 471 variations were consequently higher (100 to 1000 times) and the sensitivity of ${ }^{222} \mathrm{Rn}$ concentrations to pressure changes was less obvious than stated at Weyburn. This renders 473 improbable an origin related to transient phenomena affecting the pressure.

474 Even if not really successful during the monitoring period, long-term measurements of soil 475 gas emanations are of strong interest in view of CCS applications. Data main not only be 476 gathered on the ${ }^{222} \mathrm{Rn}$ phase but mostly on $\mathrm{CO}_{2}$ and/or $\mathrm{O}_{2}$ phases. This is crucial for assessing 477 if variations are linked to natural processes, either originated from surface processes or deeper 478 ones, or caused by CCS operations. Continuous monitoring is not designed to cover great 479 areas, one limiting factor being costs, but is complementary with point techniques and may be 480 deployed in most prominent locations highlighted by point monitoring.

\section{Chemistry of mineral waters}


483

The Sainte-Marguerite site offers the opportunity to monitor gas escapes into more or less mineralised water bodies. We will first describe water chemical compositions and then discuss what is important in view of long term water monitoring.

\subsection{Point sampling}

Mineralisation of these waters form two groups, one rich in dissolved constituents and belonging to the $\mathrm{Na}-\mathrm{Cl}-\mathrm{HCO}_{3}$ end-member, the other (Chapelle springs) more influenced by the $\mathrm{Ca}$ and $\mathrm{Mg}$ species. This distinction remains when referring to $\delta^{18} \mathrm{O}$ and $\delta \mathrm{D}$ isotope ratios (Table 2). Chapelle springs are always under the local meteoric water line (Fouillac et al., 1991), i.e. enriched in heavy isotopes contrary to other springs which fall on this meteoric water line. This may be related to evaporation (Négrel et al.,1997b and references therein), to mixing in various proportions between deep and surface end-members (e.g. Michard et al., 1981) or to mixing between different deep end-members (Négrel et al., 1997b; Rihs et al., 2000). These differences in isotope ratios denote spatial disparities within walking distance but do not imply the existence of compartmented geological structures. Theoretical calculations of the ${ }^{13} \mathrm{C}$ isotope signature of gas in equilibrium with the waters provide ratios between -2.8 and $-5.1 \%$ (Table 2 ) that exactly match the range measured in soil gas. Water mixing must then occur under open system conditions allowing different end-members to interact one with each other, pro parte explaining temporal variations reported in the area (Négrel et al., 1997b).

Strontium isotope ratio of water $\left({ }^{87} \mathrm{Sr} /{ }^{86} \mathrm{Sr}\right)$ is known to derive from that of minerals with which the water interacts and to be lower than that of the whole rock, in response to different dissolution rates between the mineral species (e.g. Michard et al., 1978). ${ }^{87} \mathrm{Sr} /{ }^{86} \mathrm{Sr}$ ratios (Table 2) suggest that Tennis and Geyser Brissac waters fall in the range of ratios known across the Limagne d'Allier (0.71338; Stettler, 1977) and therefore reflect the signature of a 
508 deep end-member. Lower ratios of Chapelle springs suggest either an interaction with 509 lithologies different from those present in the supply circuit of Tennis and Geyser Brissac 510 springs (e.g. plagioclase from the Coudes granite at 0.71028; Rihs et al., 2000) or a mixing 511 with near surface groundwaters (ratio close to 0.71102; Négrel et al., 1997b). In the first case 512 (mixture of 2 groundwaters, one coming from plagioclase weathering), a contribution of the 513 deep end-member (represented by Geyser Brissac or Tennis springs) close to $32 \%$ can be 514 calculated using a binary mixing law, whereas in the second case (dilution by surface water), 515 the proportion of the deep end-member may be close to $57 \%$.

517 Using this deep end-member - or at least the end-member less affected by mixtures 518 equilibrium temperatures with basement rocks may be evaluated referring to cationic 519 geothermometers. As geothermometers induce the existence of equilibrium between waters 520 and rocks, we neither refer to $\mathrm{Ca}$ and $\mathrm{Mg}$ geothermometers, strongly affected by mixing processes (Michard et al., 1981), nor to silica -rich species, oversaturated with water at the 522 spring orifice. Na/K (Michard, 1979, 1990, Truesdell, 1975) and Na/Li (Fouillac and 523 Michard, 1981; Michard, 1990) geothermometers are preferred as saturation indices of 524 mineral species containing $\mathrm{Na}$ indicate under saturation with water. Deep reservoir 525 temperature is estimated between 180 and $210^{\circ} \mathrm{C}(\mathrm{Na} / \mathrm{K})$ and 195 and $205^{\circ} \mathrm{C}(\mathrm{Na} / \mathrm{Li})$. This estimate is in agreement with that of Fouillac and Michard (1981) and Fouillac (1983).

528 Isotope characterisation of waters is often restricted to the monitoring of ${ }^{18} \mathrm{O},{ }^{2} \mathrm{H}$ or ${ }^{13} \mathrm{C}$ 529 species in view of CCS problematic. Such characterisation is important but water monitoring 530 of deep aquifers, such as the storage complex itself of overlying aquifers, may include other 531 species. $\mathrm{O}, \mathrm{H}, \mathrm{C}$ species may suffer from several processes such as water/rock interaction of 532 mixing between different water bodies. Monitoring other isotopes, such as $\mathrm{Sr}, \mathrm{Nd}, \mathrm{B}, \mathrm{Li}, \mathrm{Ca}$ 
or $\mathrm{U}$ may also allow getting information on deep seated processes, better define water/rock

534 interaction or describe redox processes. A better comprehension of deep phenomena may 535 allow improved constraint on $\mathrm{CO}_{2}$ migration in deep horizons if leakage from the storage reservoir may occur.

\section{$\underline{5.2 \text { Continuous monitoring of Geyser Brissac }}$}

539 Here we describe short-term evolution of some key physico-chemical parameters of the 540 Geyser Brissac mineral water. Requirements of CCS monitoring will obviously not imply 541 high frequency measurements but one must be confident on the short time scale before 542 assessing variations of longer period.

543 Results of this monitoring are presented in Figure 10 and Table 4. Two days were 544 characterised by sunny conditions whereas rainfall events of variable magnitude occurred 545 during day 4 and especially day 3. The evolution of dissolved $\mathrm{CO}_{2}$ is reported on Figure 10 546 even if quantification is not accurate using pH-based sensors (Gal et al., 2011), in order to 547 bring qualitative information.

549 Figure 10

550 Table 4

552 A cyclical pattern is clearly apparent for all the parameters, directly related to Geyser Brissac 553 dynamics (Figure 10). Two parameters mainly influence the water temperature: 1) intrinsic 554 processes, the eruption of the geyser progressively warming the water and 2) atmospheric 555 forcing, higher water temperatures being recorded around 16:00 in the evening. This is due to 556 to the location of the Geyser Brissac, emplaced in a $1 \mathrm{~m}$ deep, $5 \mathrm{~m}$ diameter bowl filled with 557 mineral water. Measurements were performed at the bottom of this bowl, closest to the drain 
where the geyser overflows. The presence of non-flowing waters induced the occurrence of

559 thermal forcing on this water mass: time is needed for the water directly flowing from the 560 geyser when it erupts to warm up the bowl. Similarly, amplitude of the temperature peaks 561 becomes smaller through the day and the water mass becomes hotter as solar heats the water 562 mass. Dilution effects due to rainfall may happen and significantly affect the water 563 temperature and the specific conductance (day 3, Table 4).

564 Apart from external causes, time evolution of the records is dependent from the geyser 565 activity. Temperature peaks, which correspond to the maximum of the activity of the geyser, lasted 4 to 5 minutes. They are synchronous to increase of the dissolved $\mathrm{CO}_{2}$, slight decrease of the $\mathrm{pH}$ value $\left(-0.05 \mathrm{pH}\right.$ unit) and decreases of the dissolved $\mathrm{O}_{2}$ concentration and of the redox potential. Such evolutions are self-consistent and reflect the progressive replacement of

$569 \mathrm{O}_{2}$ by $\mathrm{CO}_{2}$ in the bowl as the eruption takes place. Specific conductance is also affected, $\mathrm{CO}_{2}$ 570 inflows leading to harmonic variations of the record. Nevertheless, diurnal heating affects the 571 dissolved $\mathrm{CO}_{2}$ measurements, one of the drawbacks of this sensor elsewhere reported (Gal et 572 al., 2011).

574 Spectral density analysis is best constrained using dissolved $\mathrm{O}_{2}, \mathrm{pH}$ and redox potential redox. 575 Main period is around $22 \pm 1$ minutes in good agreement with infrared measurements 576 performed in soils (see section 4.2). As measurements were not conducted over several days, 577 it is not possible to identify periodicity of greater wavelength such as that determined from 578 Barasol probe acquisitions.

579 Long-term monitoring of water bodies is one of the key procedures in order to ensure of the 580 safety of $\mathrm{CO}_{2}$ storage. Monitoring performed at Sainte-Marguerite natural analogue shows 581 that this method is sensitive to strong $\mathrm{CO}_{2}$ leakage well over thresholds expected in deeper 582 environments. Nevertheless devices have the capacity to record variations of lower 
magnitude. The main issue nowadays existing relies on the stability of the sensors over time.

584 Long-term deployment at depth generally involves CTD probes, i.e. probes that measure only temperature, specific conductance and depth. This only involves solid state sensors. Idronaut probe has chemical sensors for all other parameters and such sensors are subject to drift. Dissolved oxygen may be better constrained using optical sensors. Until now, no long-term $\mathrm{pH}$ or redox monitoring has been reported without frequent recalibration of the devices. This question is of crucial importance, as $\mathrm{pH}$ is one of the most sensitive parameter to monitor changes linked to $\mathrm{CO}_{2}$ dissolution.

\section{Concluding remarks}

593 This case study of Sainte-Marguerite natural analogue allows investigating both soil gas and 594 water compartments.

595 Point soil gas measurements have suggested the presence of perennial pathways that favour 596 gas escape from depth to the surface by comparing data acquired 15 years apart. Leakage does not occur along all the fault length as may be derived from geological maps but rather along

598 discrete sections. At Sainte-Marguerite there is no visual impact on the vegetation as could 599 exist in other similar environments (Krüger et al., 2011; Schütze et al., 2012). Permeability of 600 faults does not exist as a whole mechanism but rather as narrow structures separated by less

601 permeable sections filled by secondary mineralization. In terms of CCS monitoring strategy, 602 this suggests that potential pathways that may be deduced from geological or geophysical 603 works may not be the most prone to become pathways. It would be better to search for 604 structures that are still open to fluid draining i.e. secondary fractures that are more likely to 605 have intrinsic permeability than main discontinuities.

606 The $\mathrm{CO}_{2}$ gas was found to be the main carrier gas leading to the existence of gas anomalies in 607 near surface environments. Carbon isotope ratios are mainly imprinted from deep seated 
processes with little interaction in near surface environments either resulting from percolation

609 into surface waters or into travertines horizons. Helium concentrations measured in $\mathrm{CO}_{2}$-rich

610 areas also highlighted this strong imprint of crustal contribution (Jeandel et al., 2010). The

611 interaction of fluids with travertine deposits also influenced the ${ }^{222} \mathrm{Rn}$ concentrations of the

612 gas phase. Consequently, gas emanations were found to be mainly oriented along known

613 regional directions of the tectonics with some complications induced by local surface geology.

614 When alluvial deposits were the less developed the gas emanations were stronger. Thicker

615 alluvial deposits were found to be less representative of the deep end-member due to more

616 pronounced interaction with these formations. Gas migration from depth is a highly complex

617 phenomenon that must be better constrained in order to build confidence in safety rules and

618 remediation strategies of CCS projects. Even at the upper level, near surface features have a

619 strong influence on degassing pattern as pointed out by coupled geochemical/geophysical 620 investigations (Schütze et al., 2012).

621 Soil gas surveys performed under "point acquisition" schematic are relevant for the thorough 622 description of surface leakage over a restricted spatial array. They are not fully appropriate for 623 the monitoring of large areas and may be time consuming for repeated data acquisitions. They 624 do not allow to take into account for the variability linked to external causes such as climatic 625 variability and its imprint on surface environments. They are nonetheless crucial to best settle 626 monitoring equipment for long-term surveillance. Investigation done at Sainte-Marguerite 627 was mostly oriented on the ${ }^{222} \mathrm{Rn}$ specie. It allowed highlighting excursion from background 628 noise under "gas burst" event. Such events were characterised by influence radius of at least $629200 \mathrm{~m}$. Scaling effects in case of leakage from CCS storage may not allow to get such 630 amounts of gases percolating up to the surface.

631 Therefore, there is also a need to monitor integrative bodies such as aquifers. In nearly all 632 cases, CCS sites are more or less deep and overlying aquifers exist. Monitoring aquifers in the 
633

634

635

636

637

638

639

640

641

642

643

644

645

646

647

648

649

650

651

652

653

654

655

656

657

case of natural leaking analogues is from one side little frustrating as the initial composition of the waters is not known - water properties prior leakage from a CCS site are known a priori - but on the other hand these waters represent an opportunity to study deep degassing through the interaction with water and rocks - that will be the case for CCS sites. The harmonic pulsation of Geyser Brissac is an extreme case relying on the accumulation of gas until the degassing due to overpressure.

Point monitoring of waters is by definition subject to heterogeneity of spatial coverage, ways to collect samples being restricted to available outlets or wells. Constraints on chemical processes occurring at depth may be brought by specific characterisation of the dissolved constituents and by related isotopic systematics. Particularly, the determination of mixing processes and their influence is important, as leakage from CCS site may be evidenced through the mixing of the water from the storage complex and overlying aquifers. Such methodology is not restricted to dissolved constituents and can also be extended to associate gases such as ${ }^{4} \mathrm{He}$ (Gilfillan et al., 2011).

As for soil gases, monitoring at regular frequency of water bodies is complementary with point methods. Time scale of recording depends on the kinetic of the processes. At SainteMarguerite such monitoring was performed at high frequency in order to take into account variations over short time scales, cyclicity of the geyser being around 22 minutes. Most prominent variations were stated for $\mathrm{pH}$, dissolved oxygen, redox potential and dissolved $\mathrm{CO}_{2}$ content. From soil gas measurements it was also stated that geyser "breathing" influences the soil gas evolution over short periods at a radius close to $20-30 \mathrm{~m}$.

Several conclusions arise when moving from analogue scale to industrial scale. Basically studies devoted to CCS projects separate into baseline data acquisitions, then monitoring actions during the injection and final monitoring operations after well closure and 
658 abandonment. Baseline studies are essential as they represent the only data that will allow 659 definition of anomalies during injection and post-injection. Establishing baseline values is a 660 site-specific procedure but often their definition is based on a restricted dataset of 661 measurement over limited time in order to match scientific issues on one side and industrial 662 approach on the other side.

663 Natural analogue monitoring suggests that data acquisition should not be restricted in narrow 664 perimeters above the storage complex itself but should encompass all the areas that may 665 potentially be affected by leakage. One of the main concerns is the capability of the 666 monitoring system to detect potential leaks. Anomalies are often restricted on narrow areas at 667 surface and deploying monitoring devices on such small grids (20 to $200 \mathrm{~m}$ of array) is 668 absolutely unrealistic if only considering costs. At surface, apart from such a net, it is 669 therefore hypothetical to ensure a safely monitoring over great distances simply using 670 punctual and point methods. Installation of equipment just above a potential leaking pathway 671 that may not have been recognized by geological studies would be too lucky to be reproduced 672 regularly over several deep $\mathrm{CO}_{2}$ storages. Surveying methodologies are nowadays adapted to 673 integrate gas emanations characteristics from hectometer to kilometer scales. Methods such as 674 eddy covariance, open path laser, airborne hyper-spectral monitoring etc... are promising 675 ones but until now they are not as robust as required for storages monitoring as they are often 676 dependent from modeling of the atmosphere compartment that is strongly turbulent over short 677 time periods and may therefore induce undesirable effects and false warnings (e.g. Klusman, 678 2011).

679 Ways to overcome this limitation may be of several types. Monitoring at depth through 680 boreholes, using geochemical and/or geophysical methods, appears to be the best way to get 681 early detection and warning of unexpected events by focusing on the water phase and on 682 dissolved gas contents. Monitoring should be performed under continuously deployed devices 
683

684

685

686

687

688 question.

689

690

691

692

693

694

695

696

697

698

699

700

701

702

703

704

705

706

\section{$\underline{\text { References }}$}

or at least consisting in repeated measurements. Nevertheless, from a geochemical point of view, lot of the available monitoring equipment that may be deployed at depth has nowadays not reached the desirable level of reliability over long time periods.

Many efforts have been done in recent years to adapt technologies to CCS monitoring and to gain confidence in results, but long-term recording of parameters remains a challenging

\section{$\underline{\text { Acknowledgments }}$}

This research was conducted through the fundings of French Research Agency projects Geocarbone Monitoring (2006-2008) and Sentinelle (2008-2011). Anne Bonhomme (Les Mousquetaires Group) is warmly thanked to allow the access to the Sainte-Marguerite site and subsequently fruitful data acquisition. BRGM people that performed laboratory analyses are gratefully acknowledged.

Two anonymous reviewers and the associate editor are also warmly thanked for their help in improving the manuscript.

Al-Hilal M., Sbeinati M. R., Darawcheh R. (1998) Radon variations and microearthquakes in Western Syria. Applied Radiation and Isotopes, 49, 117-123.

Appora-Gnekindy I. (1992) Etude spatiale et temporelle des émanations gazeuses de quelques zones thermominérales du Massif Central Français, rapport de stage BRGM, 92 p. 
707 Bachu S. (2003) Screening and ranking of sedimentary basins for sequestration of $\mathrm{CO}_{2}$ in 708 geologic media, Environmental Geology 44(3), 277-289.

709

710 Batard F., Billet C., Risler J.J. (1978) Prospection de $\mathrm{CO}_{2}$ d'origine profonde dans le Massif 711 Central, rapport BRGM 78-SGN-466-MCE, 16 p.

712

713 Battani A., Deville E., Faure J.-L., Noirez S., Tocqué E., Jeandel E., Benoît Y., Schmitz J., 714 Parlouar D., Gal F., Le Pierrès K., Brach M., Braibant G., Bény C., Pokryszka Z., Charmoille 715 A., Bentivegna G., Pironon J., de Donato P., Garnier C., Cailteau C., Barrès O., Radilla G., 716 Bauer A. (2010) Geochemical study of the natural $\mathrm{CO}_{2}$ emissions in the French Massif 717 Central: How to predict origin, processes and evolution of $\mathrm{CO}_{2}$ leakage, OGST, vol. 65, No 4, $718 \quad 615-633$.

719

Baubron J.C., Mercier F., Rouzaire D. (1992) Eaux minérales de Sainte Marguerite (Puy de Dôme) - Prospection géochimique in situ des gaz des sols, Rapport BRGM R-36492-AUV4S-92, $35 \mathrm{p}$.

723

724

Casanova J., Bodénan F., Négrel P., Azaroual M. (1999) Microbial control on the 725 precipitation of modern ferrihydrite and carbonate deposits from the Cézallier hydrothermal springs (Massif Central, France), Sedimentary Geology 126, 125-145.

727

728 Chyi L. L., Chou C. Y., Yang F. T. et al. (2002) Automated radon monitoring of seismicity in 729 a fault zone. Geofísica Internacional, 41, 507-511. 
Das N. K., Bhandari R. K., Ghose D. et al. (2006) Explosive helium burst in thermal spring emanations. Applied Radiation and Isotopes, 64, 144-148.

733

734 735

Dégranges P., Bosch B., Derec F. (1978) Hélium et sources thermominérales en France, rapport BRGM 78-SGN-684-MCE, 22 p.

736

737 Fleischer R. L. (1981) Dislocation model for radon response to distant earthquakes. 738 Geophysical Research Letters, 8, 477-480.

739

740 Fleischer R. L., Mogro-Campero A. (1985) Association of subsurface radon changes in 741 Alaska and the northeastern United States with earthquakes. Geochimica et Cosmochimica 742 Acta, 49, 1061-1071.

743

744 Fouillac, C., Michard, G. (1981) Sodium/lithium ratio in water applied to geothermometry of 745 geothermal reservoirs. Geothermics 10, 55-70.

746

747 Fouillac C. (1983) Chemical geothermometry in $\mathrm{CO}_{2}$-rich thermal waters. Example of the 748 French Massif Central, Geothermics, Vol. 12, No. 2/3, 149 - 160.

749

750 Fouillac C., Fouillac A.M., Chery L. (1991) lsotopic studies of deep and surface waters in the 751 French Massif Central, Proceedings of isotope techniques in water resources development, 752 Vienne, 11-15/03/1991, 646-648.

753

754 Gal F., Gadalia A. (2011) Mesure des gaz des sols autour du système volcanique le plus 755 récent de France métropolitaine (lac Pavin, Massif Central). Soil gas measurements around 
756 the most recent volcanic system of metropolitan France (lake Pavin, Massif Central), C. R.

757 Geosciences 343, 43-54.

758

759 Gal F., Brach M., Braibant G., Jouin F., Michel K. (2011) $\mathrm{CO}_{2}$ escapes in the Laacher See 760 region, East Eifel, Germany: application of natural analogue onshore and offshore 761 geochemical monitoring, International Journal of Greenhouse Gas Control, 5, 1099-1118.

762

763 Gerlach T. M., Taylor B. E. (1990) Carbon isotope constraints on degassing of carbon dioxide 764 from Kilauea Volcano, GCA, 54, 2051-2058.

765

766 Ghosh D., Deb A., Sengupta R. et al. (2007) Pronounced soil-radon anomaly - Precursor of 767 recent earthquakes in India. Radiation Measurements, 42, 466-471.

768

769 Gilfillan S.M.V., Wilkinson M., Haszeldine R.S., Shipton Z.K., Nelson S.T., Poreda R.J. 770 (2011) $\mathrm{He}$ and $\mathrm{Ne}$ as tracers of natural $\mathrm{CO}_{2}$ migration up a fault from a deep reservoir, 771 International Journal of Greenhouse Gas Control, 5, 1507-1516.

772

773 Jeandel E., Battani A., Sarda P. (2010) Lessons learned from natural and industrial analogues 774 for storage of carbon dioxide, International Journal of Greenhouse Gas Control, 4, 890-899. 775

776 Kharatian K., Travi Y., Igoumnov V. (2002) Activité du gaz radon dans l'air du sol et 777 sismicité locale : exemple du bassin de l'Arax (Arménie). Comptes Rendus de Geosciences, $778 \quad 334,179-185$. 
780 Klusman R.W. (2011) Comparison of surface and near-surface geochemical methods for 781 detection of gas microseepage from carbon dioxide sequestration, International Journal of Greenhouse Gas Control, 5, 1369-1392.

783

784 Krüger M., Jones D., Frerichs J., Oppermann B.I., West J., Coombs P., Green K., Barlow T., 785 Lister R., Shaw R., Strutt M., Möller I. (2011) Effects of elevated $\mathrm{CO}_{2}$ concentrations on the 786 vegetation and microbial populations at a terrestrial $\mathrm{CO}_{2}$ vent at Laacher See, Germany, 787 International Journal of Greenhouse Gas Control 5, 1093-1098.

788 Lemieux J.-M. (2011) Review: The potential impact of underground geological storage of 789 carbon dioxide in deep saline aquifers on shallow groundwater resources, Hydrogeology 790 Journal, 19, 757-778.

791

792 Lewicki J.L., Birkholzer J., Tsang C.-F. (2007) Natural and industrial analogues for leakage 793 of $\mathrm{CO}_{2}$ from storage reservoirs: identification of features, events, and processes and lessons 794 learned, Environ Geol, 52, 457-467.

795

796 Mercier F., avec la collaboration de Ausseur Y. (1987) Fichier des eaux minérales du Puy de 797 Dôme, rapport BRGM 87-SGN-780-AUV, 222 p.

798

799 Merle O., Michon L. (2001) The formation of the West European Rift: A new model as 800 exemplified by the Massif central area, Bull. Soc. Géol. France, 172, 2, 81-89.

801

802 Michard G., Evrard M., Fouillac C., Lambert B. (1978) Acquisition des ions alcalino-terreux 803 par les eaux carbogazeuses, Earth Planet. Sci. Lett. 41, 170-174.

804 
805 Michard G. (1979) Géothermomètres chimiques. Bull. Du BRGM (2ème série) Section III 2, $806 \quad 183-189$.

807

808 Michard G., Fouillac C., Grimaud D., Denis J. (1981) Une méthode globale d'estimation des 809 températures des réservoirs alimentant les sources thermales. Exemple du Massif Central 810 Français, Geochimica et Cosmochimica Acta, 45, 1199-1207.

811

812 Michard G. (1990) Behaviour of major elements and some trace elements (Li, Rb, Cs, Sr, Fe, $813 \mathrm{Mn}, \mathrm{W}, \mathrm{F})$ in deep hot waters from granitic areas. Chem. Geol. 89, 117-134.

814

815 Michel-Le Pierrès K., Gal F., Brach M., Guignat S. (2010) Radon, Helium and $\mathrm{CO}_{2}$ 816 measurements in soils overlying a former exploited oilfield, Pechelbronn district, Bas-Rhin, 817 France, J. Env. Rad. 101, 835-846.

818

819 Négrel P., Fouillac C., Brach M. (1997a) Occurrence of mineral water springs in the the Allier 820 River (Massif Central, France): stream channel of chemical and Sr isotope constraints, Journal 821 of Hydrology 203, 143-153.

822

823 Négrel P., Fouillac C., Brach M. (1997b) Variations spatio-temporelles de la composition 824 chimique et des rapports ${ }^{87} \mathrm{Sr} /{ }^{86} \mathrm{Sr}$ des eaux minérales de la Limagne d'Allier, C. R. Acad. Sci. 825 Paris, 325, 119-124.

826

827 Ramola R. C., Prasad Y., Prasad G. et al. (2008) Soil-gas radon as seismotectonic indicator in 828 Garhwal Himalaya. Applied Radiation and Isotopes, 66, 1523-1530. 
Riding J.B., Rochelle C.A. (2009) Subsurface characterisation and geological monitoring of

831 the $\mathrm{CO}_{2}$ injection operation at Weyburn, Saskatchewan, Canada, Geological Society, London, 832 Special Publications, 313, 227-256.

833

834 Rihs S., Condomines M., Poidevin J.L. (2000) Long-term behaviour of continental 835 hydrothermal systems: U-series study of hydrothermal carbonates from the French Massif 836 Central (Allier Valley), Geochimica et Cosmochimica Acta, Vol. 64, No. 18, 3189-3199.

Schütze C., Sauer U., Beyer K., Lamert H., Bräuer K., Strauch G., Flechsig Ch., Kämpf H.,

Dietrich P. (2012) Natural analogues: a potential approach for developing reliable monitoring methods to understand subsurface $\mathrm{CO}_{2}$ migration processes, Environ. Earth Sci., DOI 10.1007/s12665-012-1701-4.

Spangler L.H. (2010) Foreword to the Special Issue on Zero Emission Research and

844 Technology Center testing field site, Bozeman, Montana, USA, Environ. Earth Sci. 60, 225.

Stettler A. (1977) ${ }^{87} \mathrm{Rb}^{87} \mathrm{Sr}$ systematic of a geothermal water-rock association in the Massif Central, France. Earth and Planet. Sci, Lett., 34, 432-438.

Truesdell A.H. (1975) Geochemical techniques in exploration, summary of section III, In:

Proceedings Second United Nation Symposium on the development and use of geothermal resources, vol. 1, pp. Iiii-Ixiii.

853 Wattananikorn K., Kanaree M., Wiboolsake S. (1998) Soil gas radon as an earthquake 854 precursor: some considerations on data improvement. Radiation Measurements, 29, 593-598. 


\section{$\underline{\text { Figure captions: }}$}

858 Figure 1: location of the study area: dots locate points where soil gas data are available: black 859 dots refer to 2006-2010 data acquisitions, red contoured dots are from the 90's dataset. Red 860 dots represent the main mineral waters that are labelled in the inset. Yellow dots (labelled 1 to 8614 4) represent points where continuous monitoring was performed. Grey lines represent main 862 roads.

863

864 Figure 2: $\mathrm{O}_{2}-\mathrm{CO}_{2}$ relationship for the 2006-2010 soil gas measurements; the equimolar 865 replacement line ( 1 mole $\mathrm{CO}_{2} \Leftrightarrow 1$ mole $\mathrm{O}_{2}$ ) is represented. Model line corresponds to the 866 regression line between the 2 species; the $95 \%$ confidence interval of the regression is also 867 indicated.

868

869 Figure 3: relationships between $\mathrm{Ar}, \mathrm{N}_{2}, \mathrm{O}_{2}$ and $\mathrm{CO}_{2}$ concentrations (\% vol.) on samples 870 analysed using laboratory gas chromatography (samples from year 2007).

871

872 Figure 4: A: Relationships between $\mathrm{CO}_{2},{ }^{222} \mathrm{Rn}$ and ${ }^{4} \mathrm{He}$ in soil gas (2006-2010 dataset); B: 873 detail of the $\mathrm{CO}_{2}-{ }^{222} \mathrm{Rn}$ relationship for low ${ }^{222} \mathrm{Rn}$ concentrations (lesser than 300,000 Bq.m ${ }^{-}$ $\left.874^{3}\right)$.

875

876 Figure 5: Relationships between $\mathrm{CO}_{2},{ }^{222} \mathrm{Rn}$ and ${ }^{4} \mathrm{He}$ in soil gas.

877

878 Figure 6: spatial distribution of soil gas species (from left to right: $\mathrm{CO}_{2},{ }^{222} \mathrm{Rn}$ and ${ }^{4} \mathrm{He}$ ) along 879 with time (from top to bottom). Interpolation is done using natural neighbour contouring. 
881 Figure 7: $\mathrm{CO}_{2},{ }^{222} \mathrm{Rn}$ and ${ }^{4} \mathrm{He}$ concentrations (2006 to 2010 measurements) recalculated in the $8820-1$ interval to lower the influence of ${ }^{222} \mathrm{Rn}$ and strengthen the one of ${ }^{4} \mathrm{He}$ (arbitrary units). 883 See text for explanation.

884

885 Figure 8: a: temporal evolution of pressure for Barasol probes (labelled as F10X) for points 2 886 and 4 (Figure 1) and comparison with atmospheric data (Clermont-Ferrand Aulnat airport; 887 http://french.wunderground.com/); b: evolution of soil temperatures and atmospheric 888 temperature (same chart as for $8 \mathrm{a}$ ); $\mathrm{c}:{ }^{222} \mathrm{Rn}$ concentrations over time; blanked areas (F109 889 probe) correspond to power supply deficiency or to electronical malfunctioning of the ${ }^{222} \mathrm{Rn}$ 890 detector.

891

892 Figure 9: F109 Barasol probe (point 4 in Figure 1); period from the 26 February 2009 to the 89307 April 2009; a: temporal evolution of soil temperature and ${ }^{222} \mathrm{Rn}$ concentrations; b: temporal 894 evolution of atmospheric pressure and ${ }^{222} \mathrm{Rn}$ concentrations; c: temporal evolution of 895 atmospheric temperature and ${ }^{222} \mathrm{Rn}$ concentrations; $\mathrm{d}$ : spectral densities of ${ }^{222} \mathrm{Rn}$ 896 concentrations; e and f: Principal Component Analysis using these 4 parameters.

897

898 Figure 10: a: temporal evolution of water temperature of Geyser Brissac during deployment; 899 b: temporal evolution of temperature $\left({ }^{\circ} \mathrm{C}\right), \mathrm{pH}$, specific conductance at $25^{\circ} \mathrm{C}\left(\mathrm{mS} \mathrm{cm}^{-1}\right)$, 900 dissolved oxygen content $\left(\mathrm{mg} . \mathrm{L}^{-1}\right)$, redox potential $(\mathrm{Eh}, \mathrm{mV})$ and dissolved $\mathrm{CO}_{2}$ (expressed as 901 a $\mathrm{mV}$ value) during the second day of deployment. 


\section{List of tables:}

904

905 Table 1: statistical parameters for the $\mathrm{CO}_{2},{ }^{222} \mathrm{Rn}$ and ${ }^{4} \mathrm{He}$ concentrations during the 90's and 9062000 's surveys (Sainte-Marguerite area; see Figure 1 for location).

908 Table 2: physico-chemical parameters of mineral waters from the Sainte-Marguerite area (see 909 location in Figure 1). Major ion contents are reported; blanks indicate a non-detection of the 910 specie or a non-measurement (isotope ratios). $\delta^{18} \mathrm{O}$ and $\delta \mathrm{D}$ isotope ratios are reported as well 911 as the $\delta \mathrm{D}$ difference to the local meteoric water line $\left(\delta \mathrm{D}=8 \delta^{18} \mathrm{O}+13.1\right.$; Fouillac et al., 912 1991). Equilibrium partial $\mathrm{CO}_{2}$ pressure is computed using Diagrammes software 913 (http://www.lha.univ-avignon.fr/).

914

915 Table 3: descriptive statistics for ${ }^{222} \mathrm{Rn}$ concentrations acquired using Barasol probes.

916

917 Table 4: top: evolution of temperature $\left({ }^{\circ} \mathrm{C}\right), \mathrm{pH}$, specific conductance at $25^{\circ} \mathrm{C}\left(\mathrm{EC}, \mathrm{mS}_{\mathrm{cm}}{ }^{-1}\right)$, 918 dissolved oxygen content $\left(\mathrm{mg} . \mathrm{L}^{-1}\right)$, redox potential $(\mathrm{Eh}, \mathrm{mV})$ and dissolved $\mathrm{CO}_{2}$ (expressed as 919 a $\mathrm{mV}$ value) along the 4 days of monitoring of the Geyser Brissac (monitoring duration 920 indicated into brackets); bottom: correlation matrix for each daily dataset. Geyser Brissac was 921 sampled on day 3 (Table 2). 


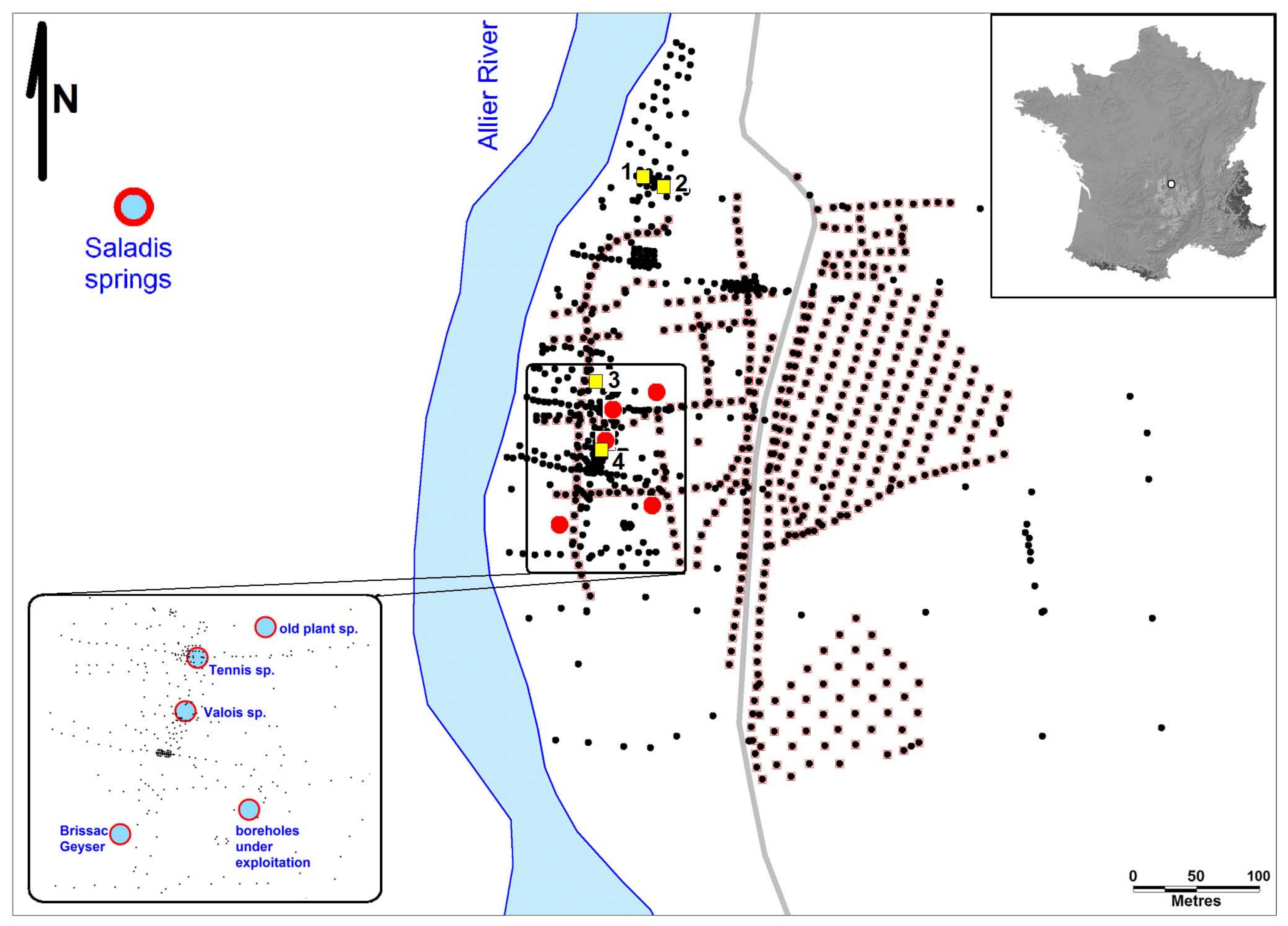




\section{$\mathrm{CO}_{2}(\%)=98.2-4.92 \times \mathrm{O}_{2}(\%)\left(\mathrm{R}^{2}=0.943 ; \mathrm{n}=566\right)$}

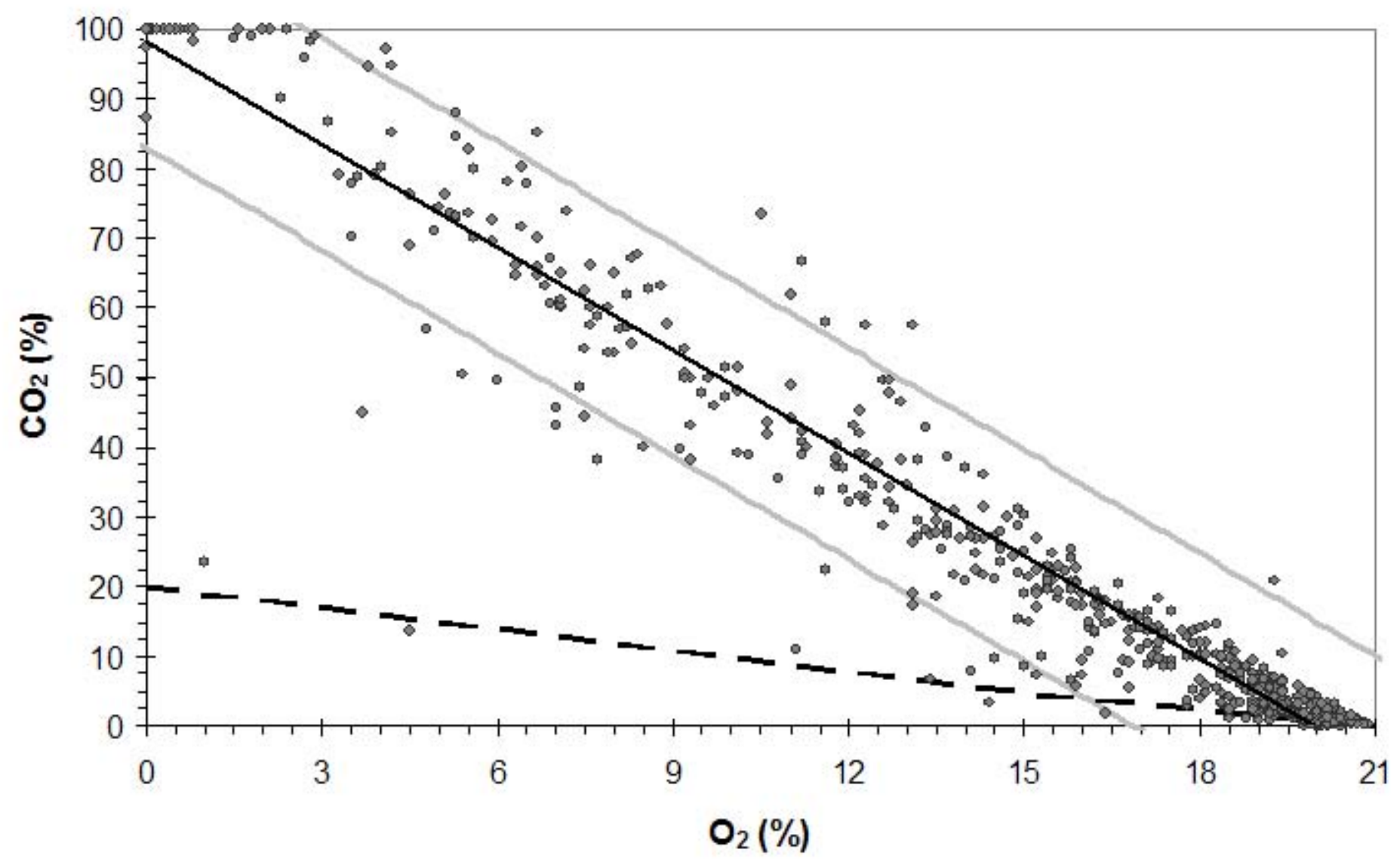




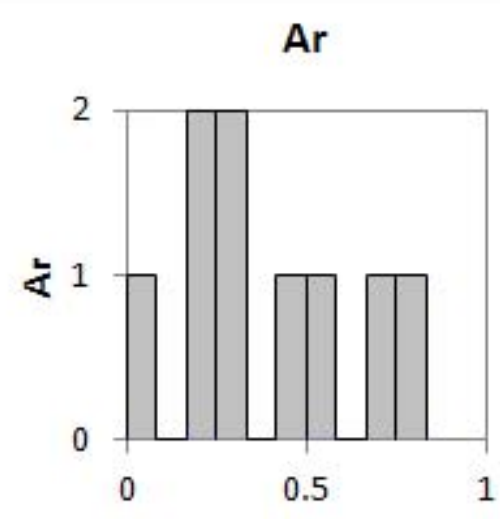

N2
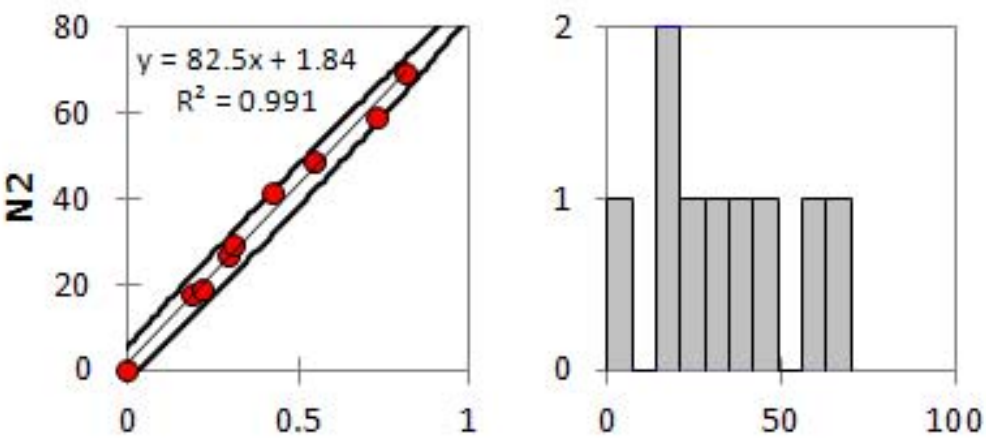

$\mathrm{CO} 2$
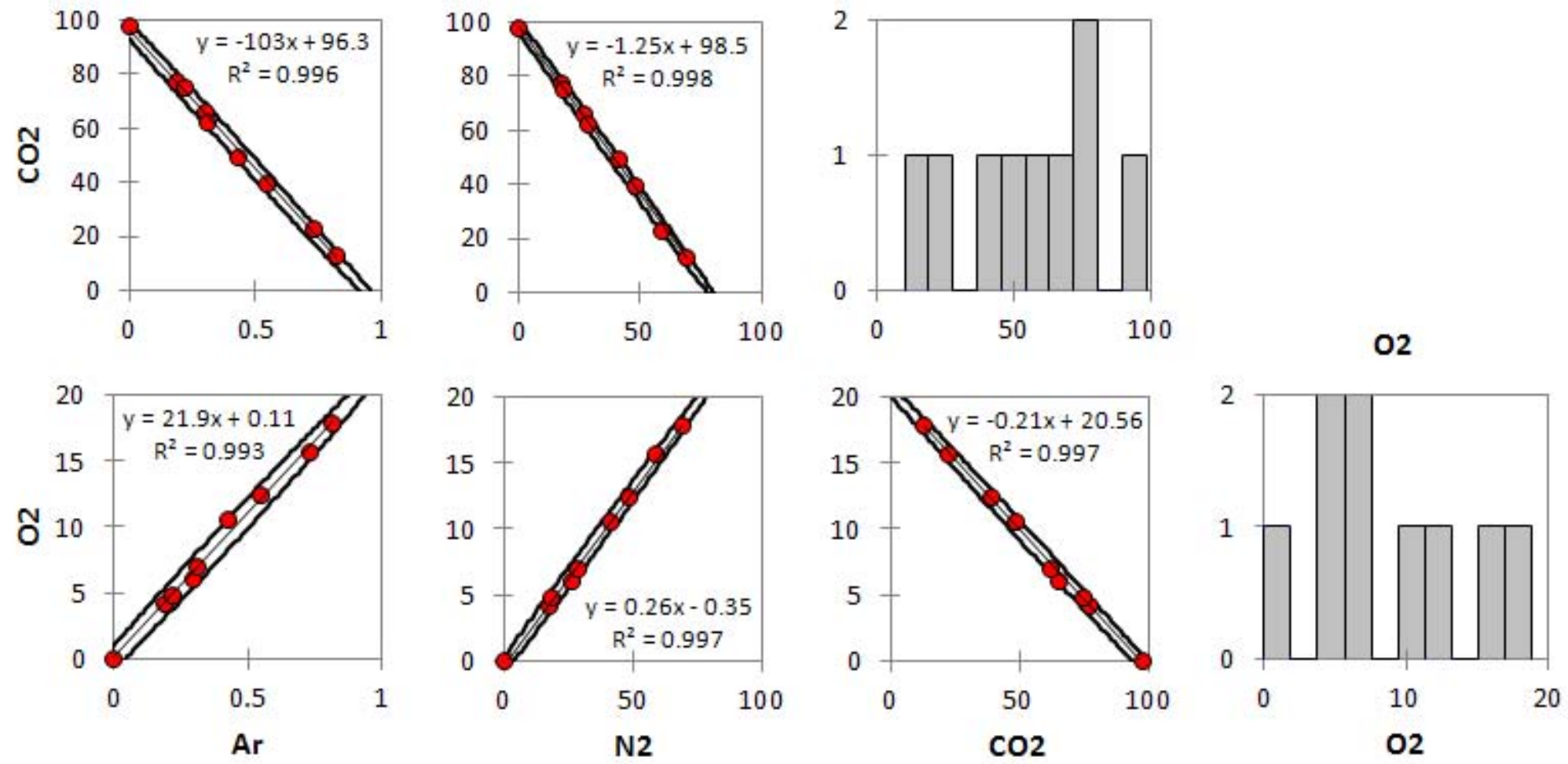

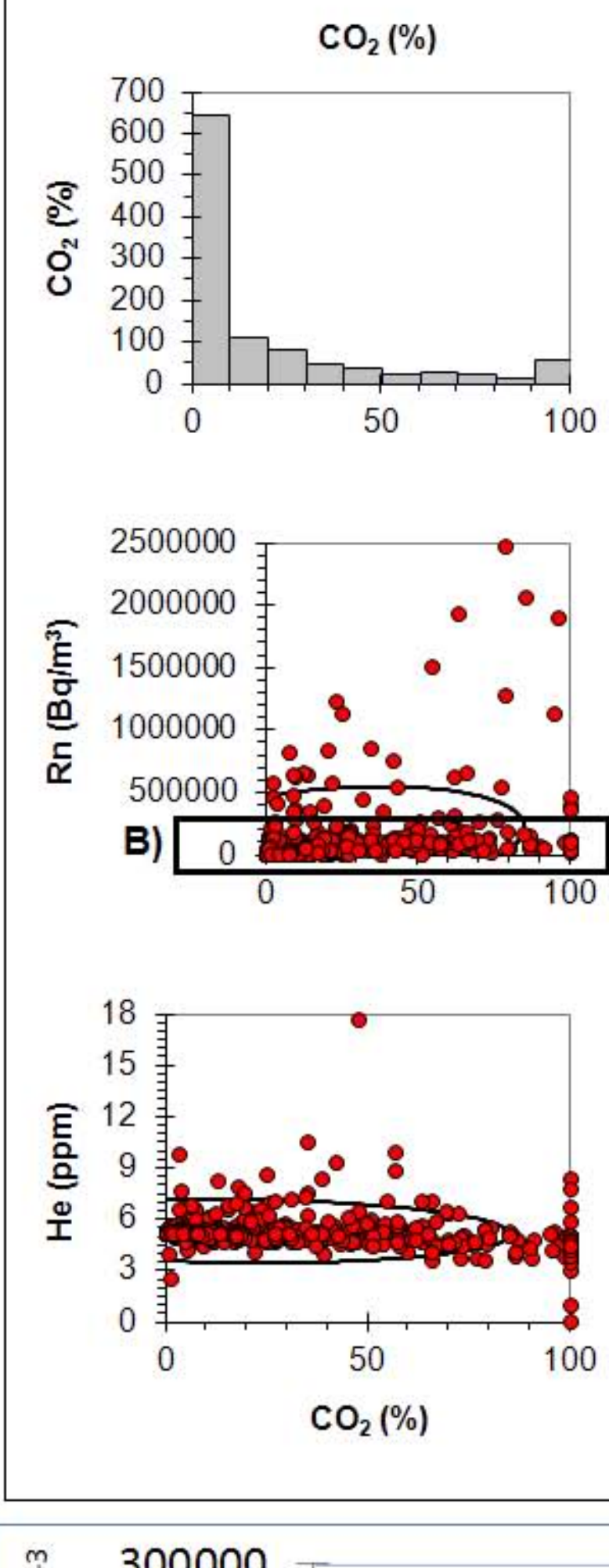

$\operatorname{Rn}\left(\mathrm{Bq} / \mathrm{m}^{3}\right)$
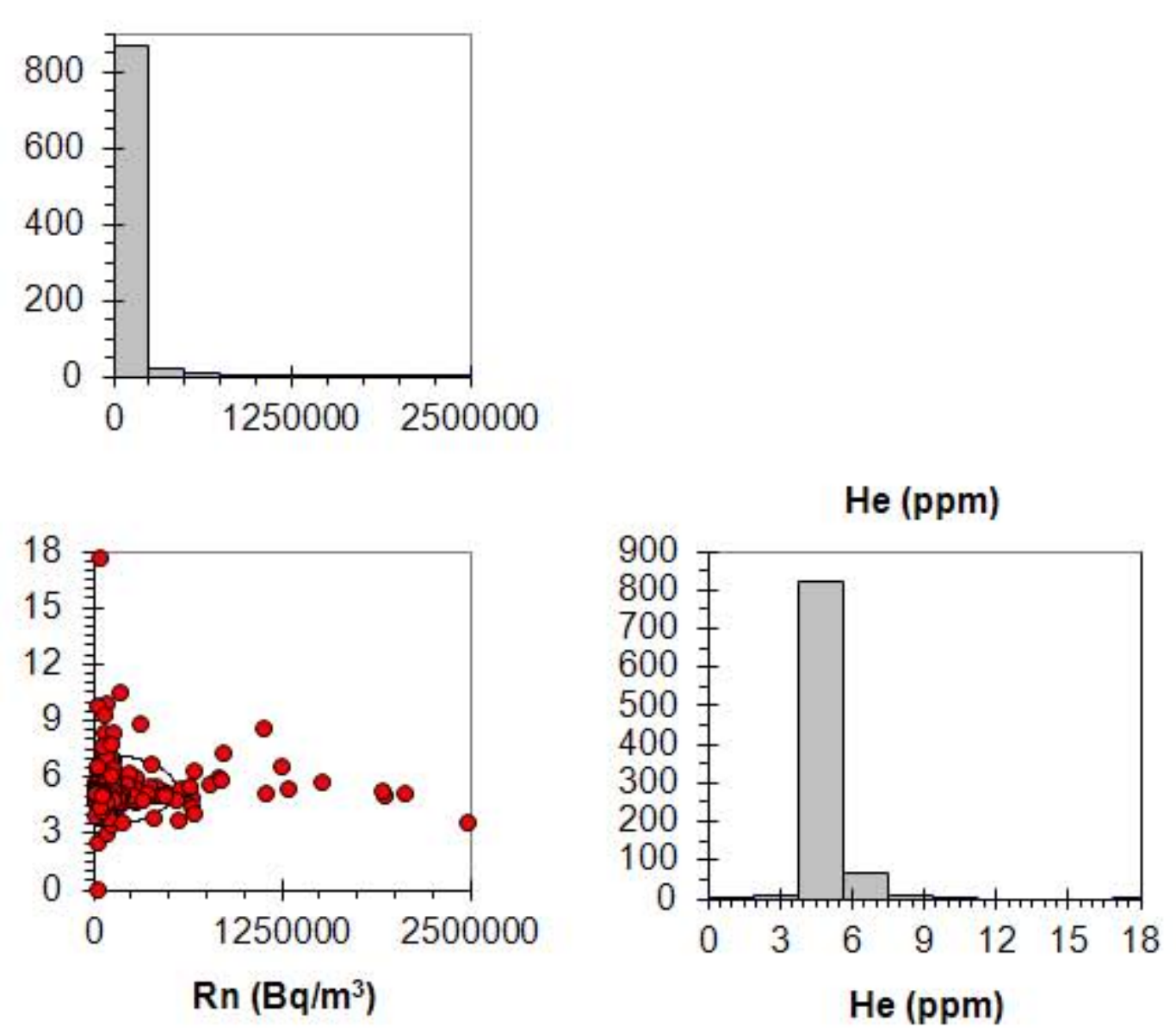

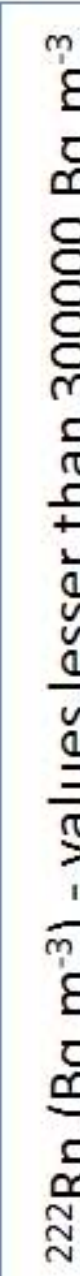
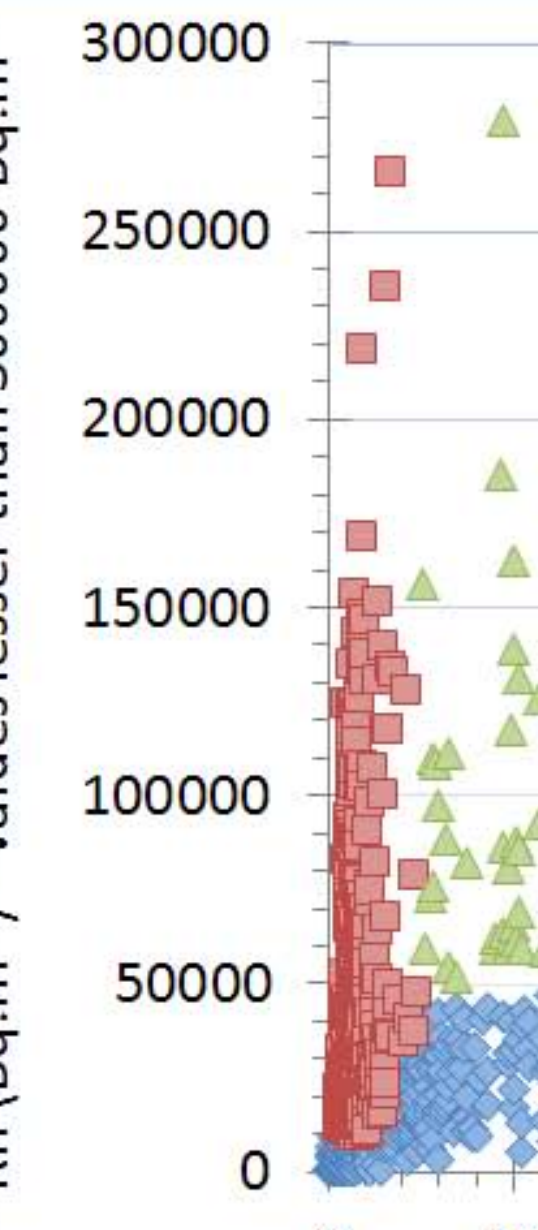

0

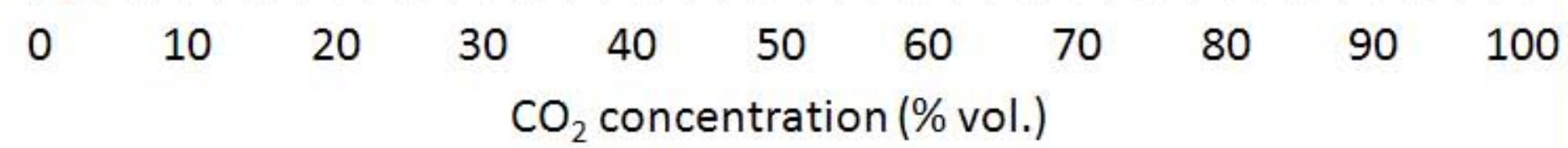

$\diamond$ slow $222 \mathrm{Rn}$ enrichment vs. CO2 enrichment

$\square$ fast 222Rn enrichment vs. CO2 enrichment 


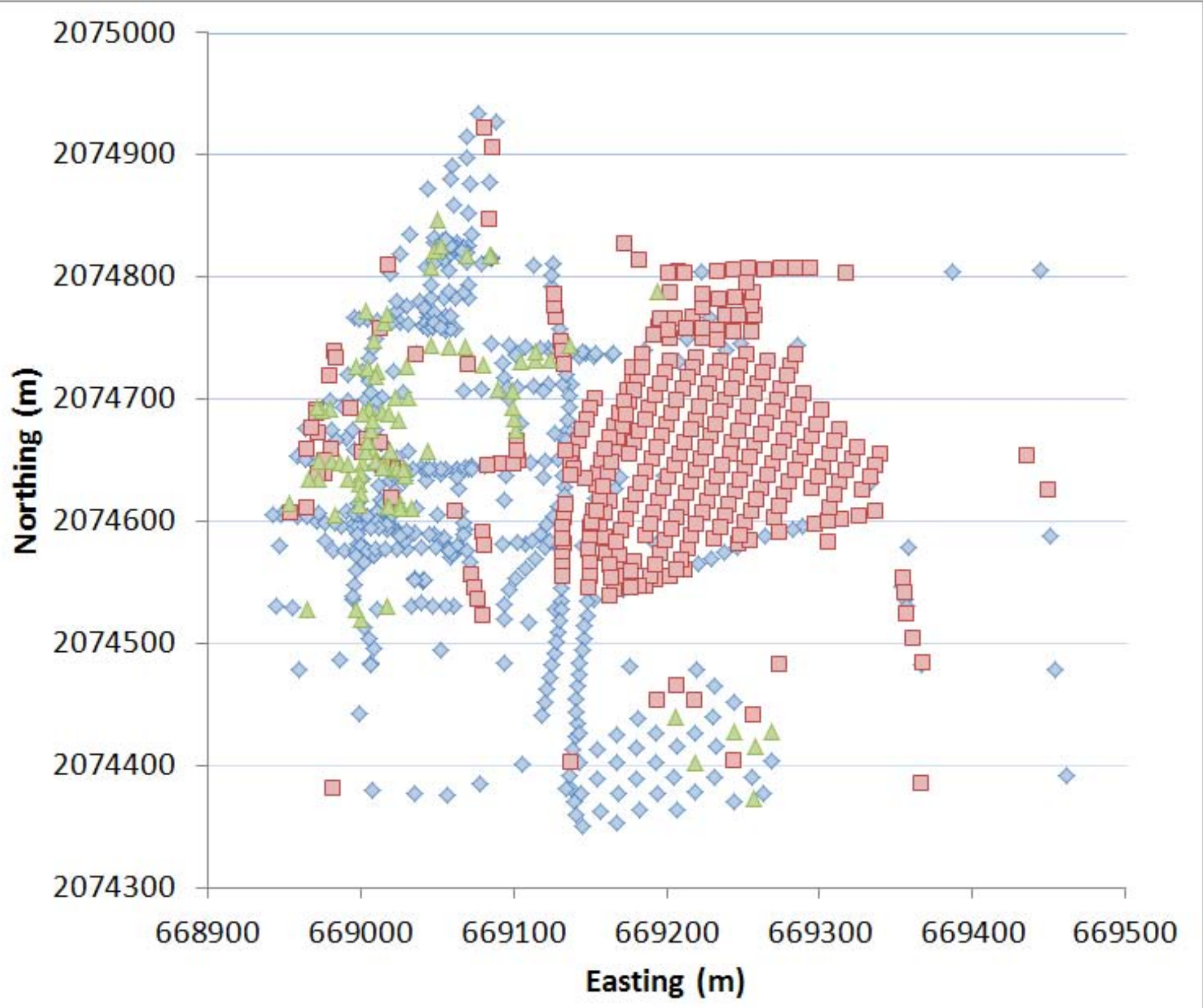

$\diamond$ slow $222 \mathrm{Rn}$ enrichment vs. $\mathrm{CO} 2$ enrichment $\square$ fast $222 \mathrm{Rn}$ enrichment vs. $\mathrm{CO} 2$ enrichment $\Delta$ intermediate tendency 


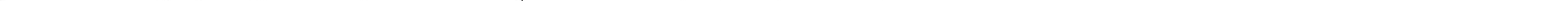


colorscale: sum of $\mathrm{CO} 2+$ radon + helium fitted in the 0 - 1 interval

greyscale: $\mathrm{CO} 2$ distribution in the same interval

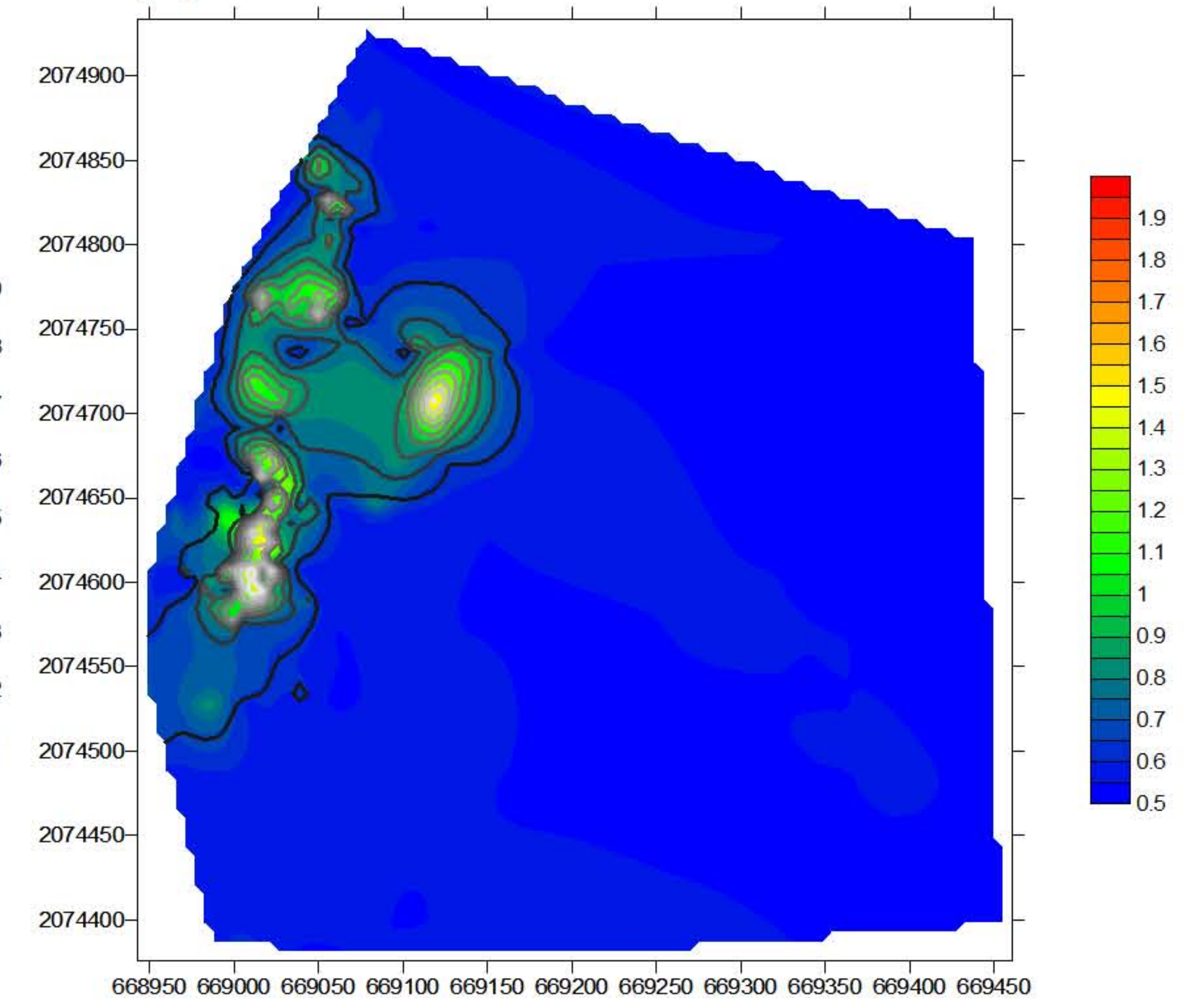

colorscale: sum of $\mathrm{CO} 2+$ radon + helium fitted in the 0 - 1 interval greyscale: radon distribution in the same interval

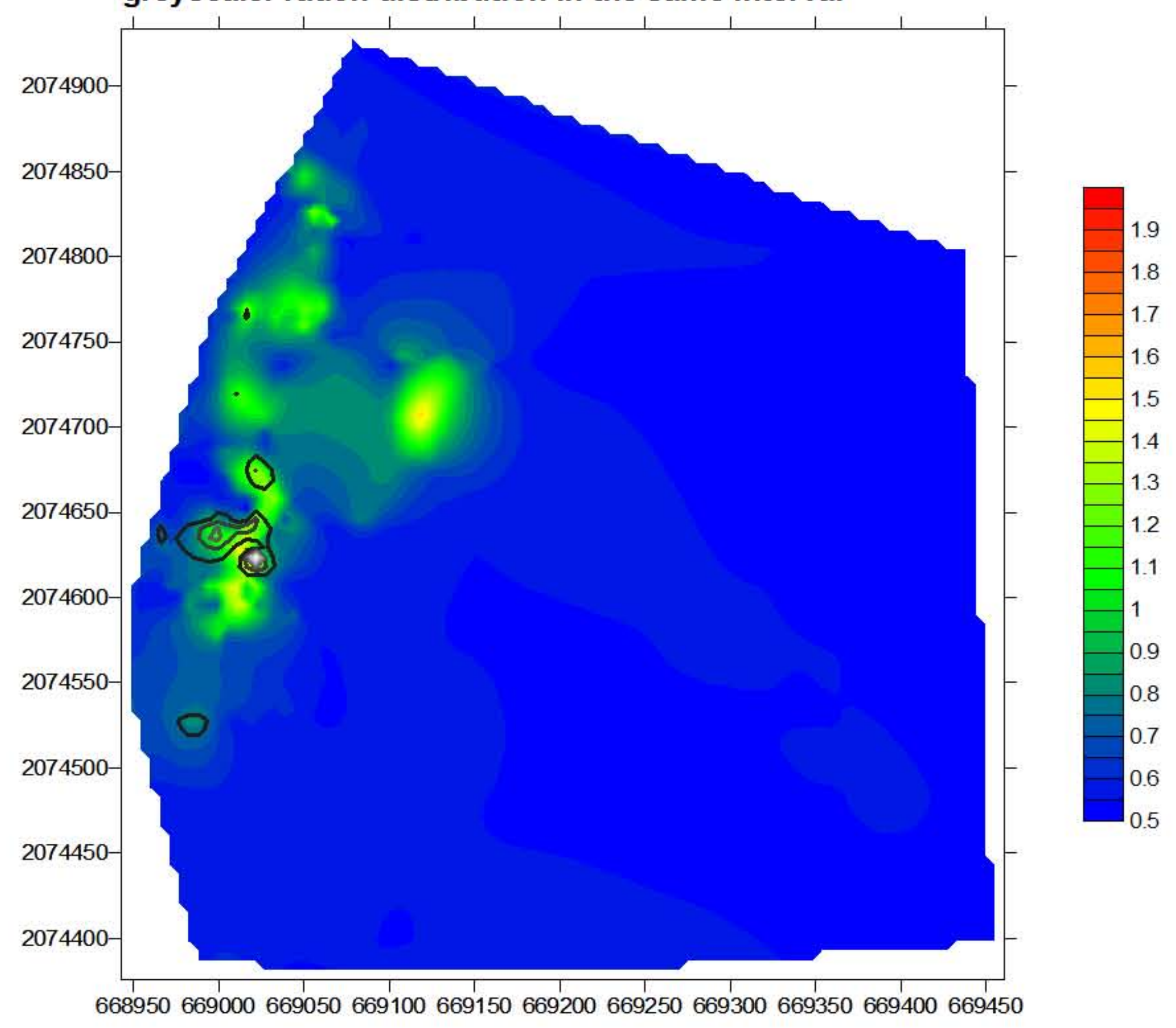

colorscale: sum of $\mathrm{CO} 2+$ radon + helium fitted in the 0 - 1 interval greyscale: helium distribution in the same interval

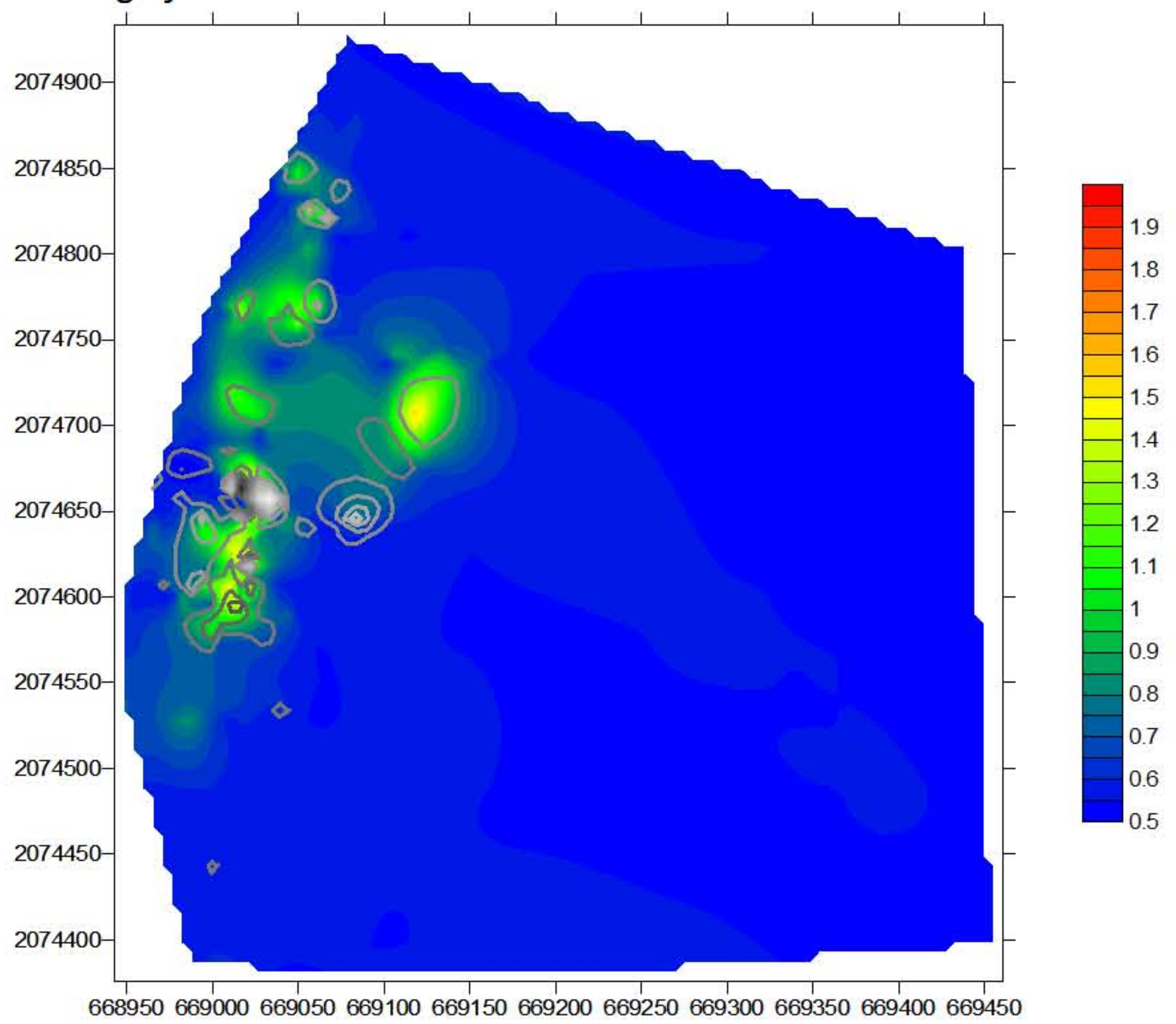



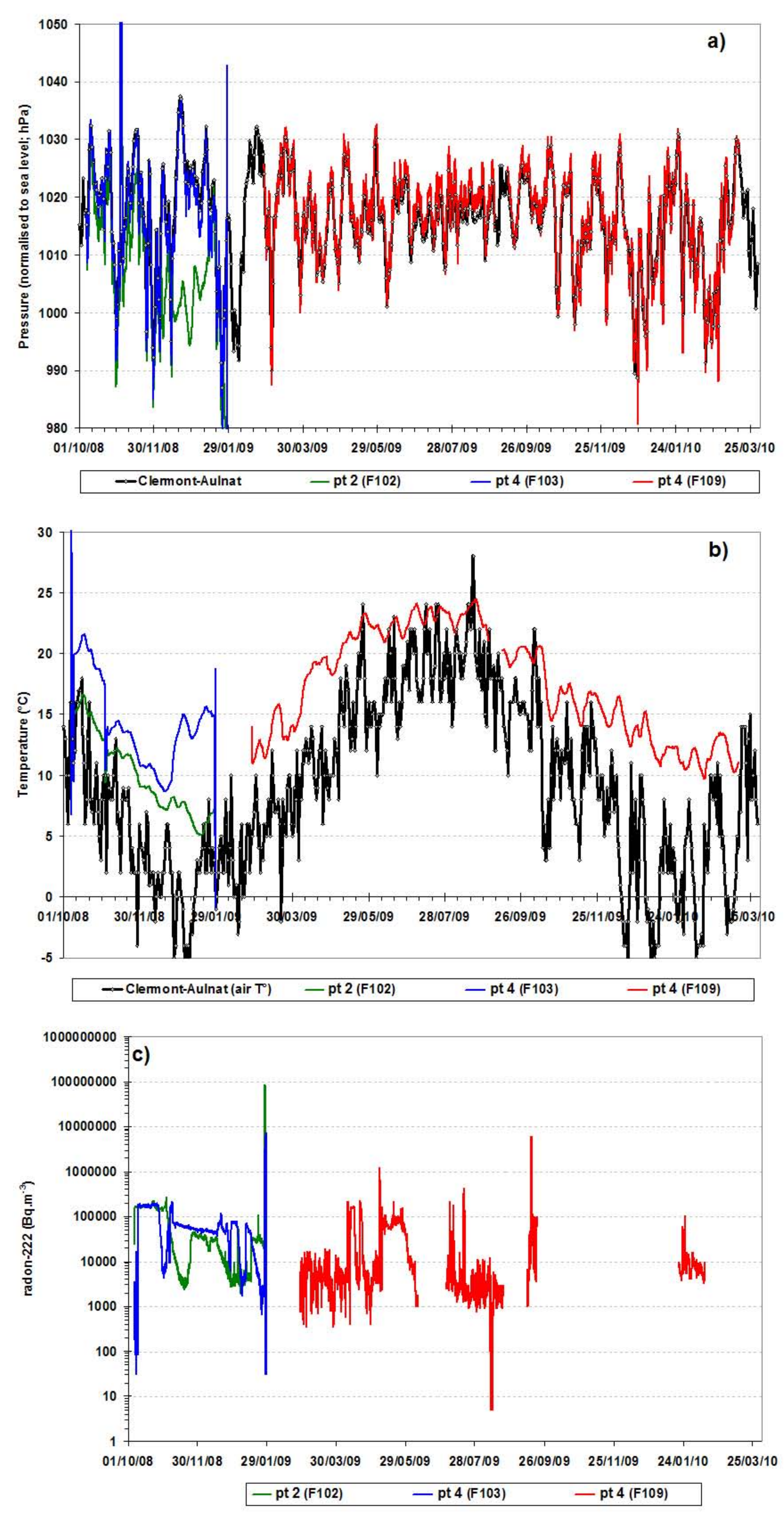

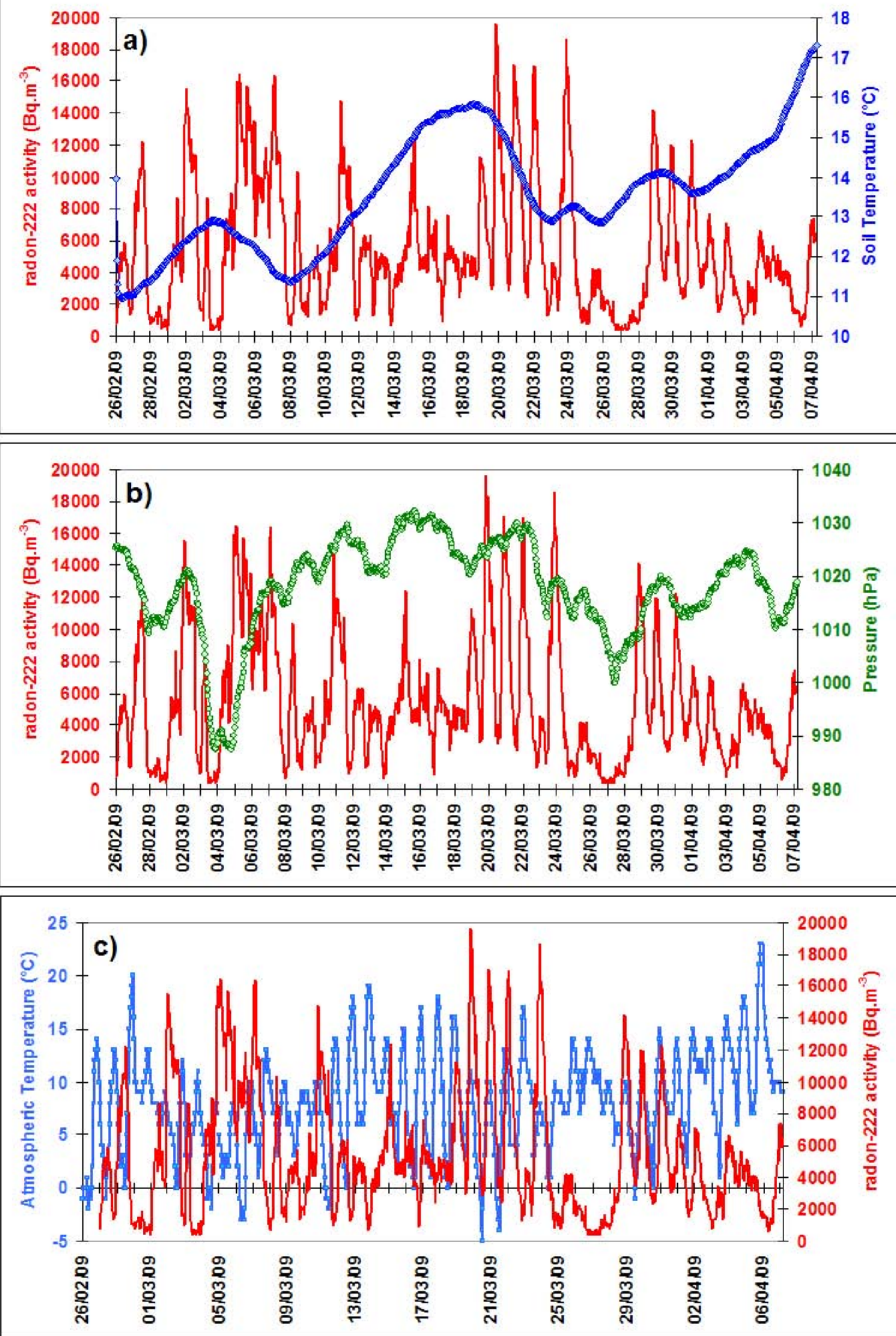

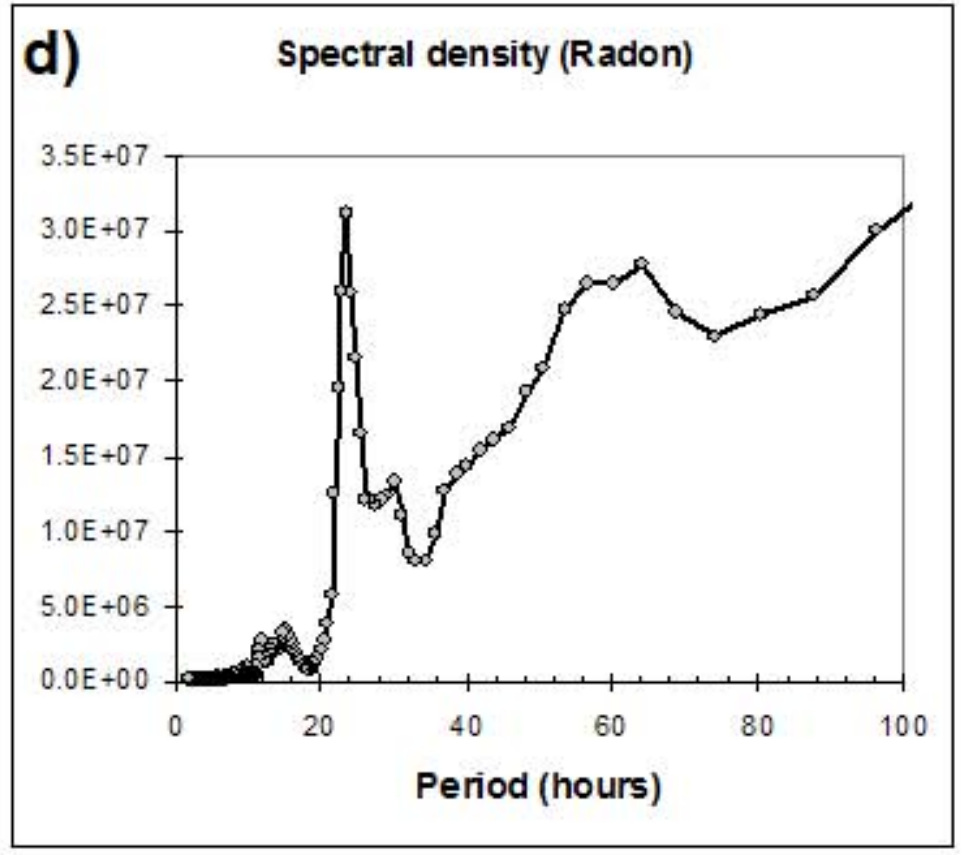

e)

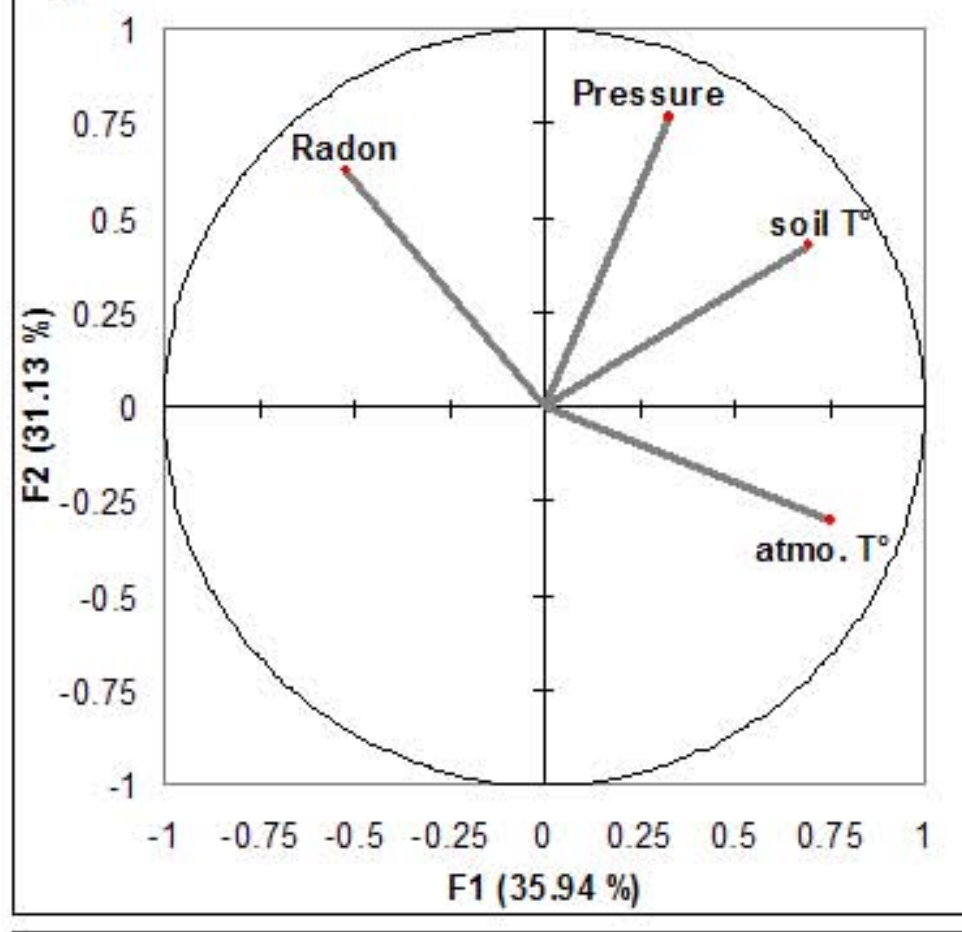

f)

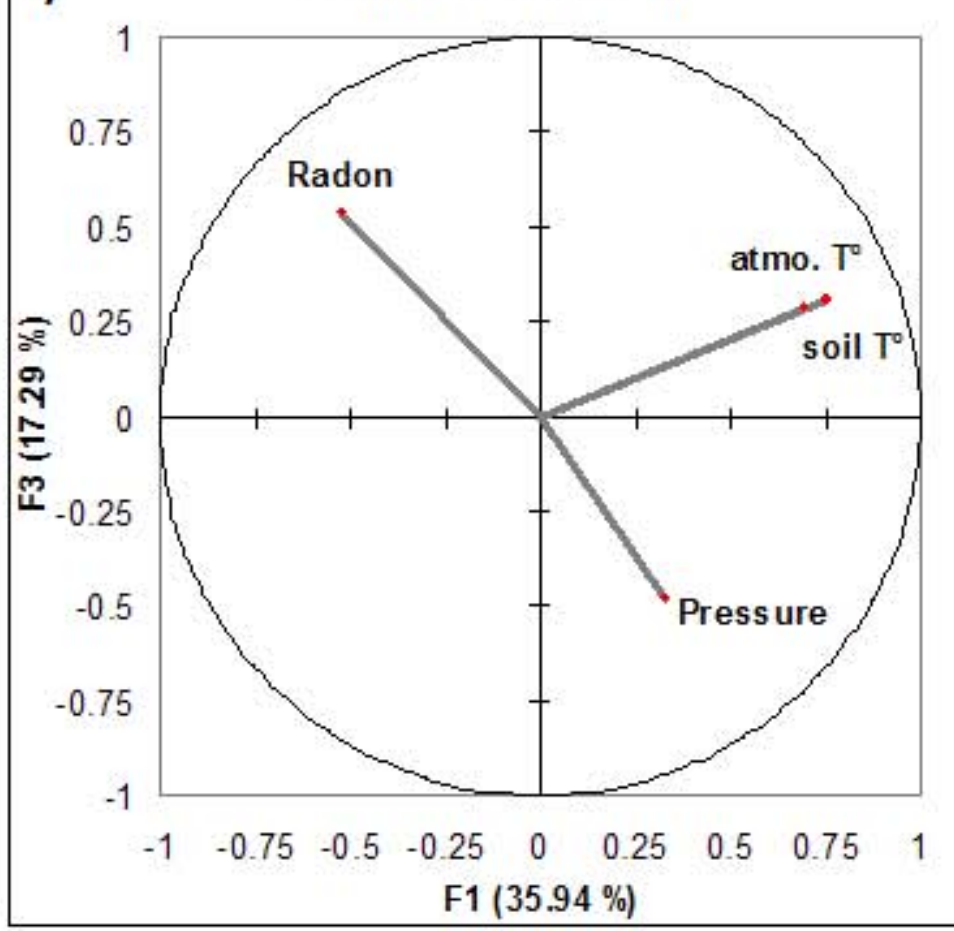


a)

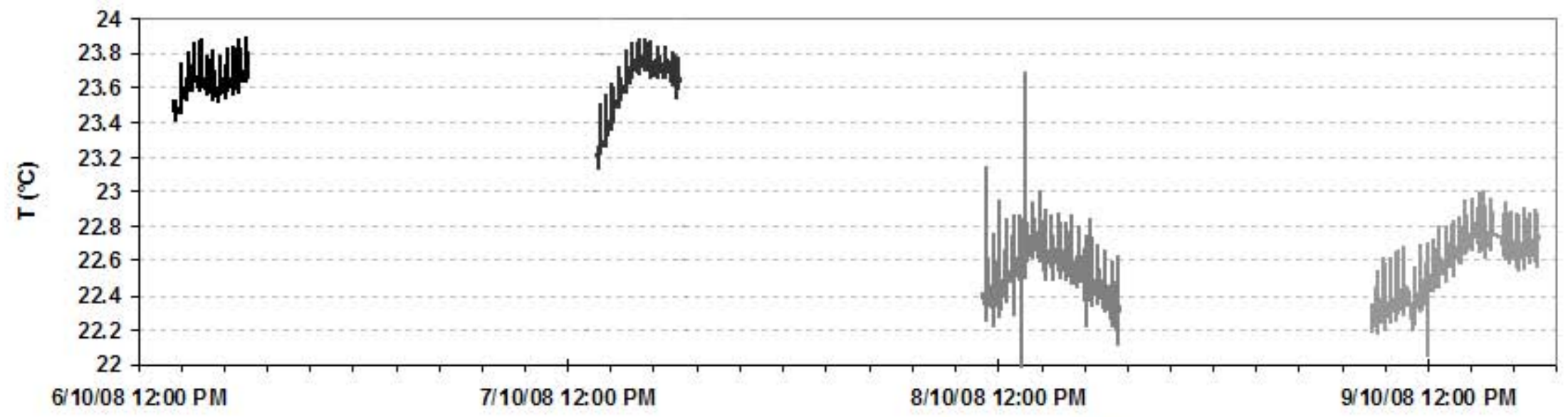

- day $-1 \quad$ day $-2 \quad$ day $-3 \quad$ day -4

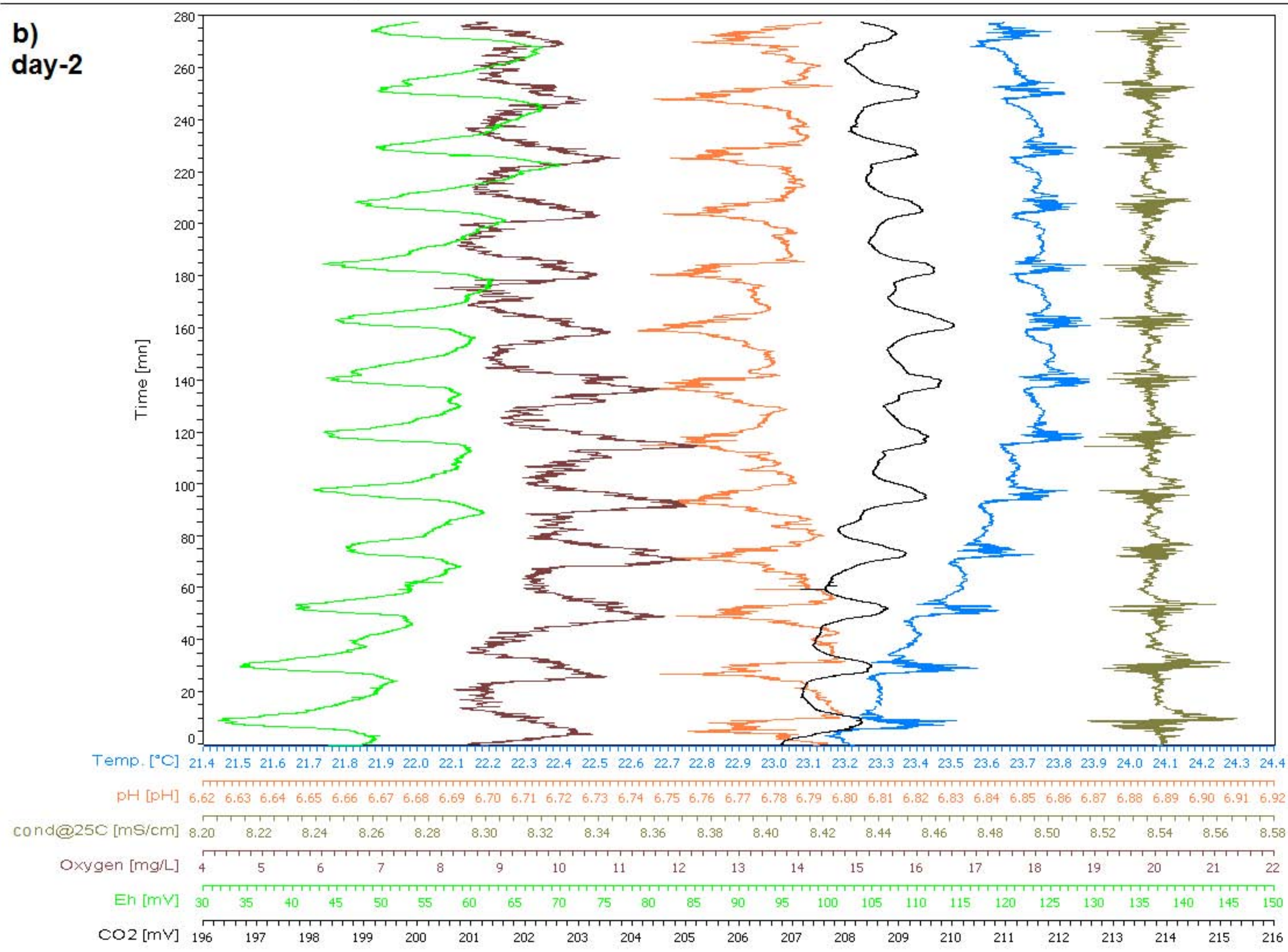




\begin{tabular}{|c|c|c|c|c|c|c|c|c|c|}
\hline & $\mathrm{CO}_{2}(\%)$ & $\mathrm{CO}_{2}(\%)$ & $\mathrm{CO}_{2}(\%)$ & ${ }^{222} \mathrm{Rn}\left(\mathrm{Bq} \cdot \mathrm{m}^{-3}\right)$ & ${ }^{222} \mathrm{Rn}\left(\mathrm{Bq} \cdot \mathrm{m}^{-3}\right)$ & ${ }^{222} \mathrm{Rn}\left(\mathrm{Bq} \cdot \mathrm{m}^{-3}\right)$ & ${ }^{4} \mathrm{He}$ (ppm) & ${ }^{4} \mathrm{He}$ (ppm) & ${ }^{4} \mathrm{He}$ (ppm) \\
\hline & all data & 1992 & 2006-2010 & all data & 1992 & 2006-2010 & all data & 1992 & 2006-2010 \\
\hline nb. of measurements & 1058 & 504 & 554 & 913 & 503 & 410 & 917 & 431 & 486 \\
\hline minimum & 0.05 & 0.08 & 0.05 & 144 & 148 & 144 & $<0.05$ & 2.58 & $<0.05$ \\
\hline maximum & 100 & 91.40 & 100 & 2482000 & 1930000 & 2480000 & 17.68 & 17.68 & 9.83 \\
\hline 1st quartile & 1.40 & 1.18 & 3.31 & 15800 & 17000 & 13800 & 5.19 & 5.24 & 5.04 \\
\hline median value & 4.64 & 1.70 & 15.76 & 39800 & 37000 & 43200 & 5.24 & 5.30 & 5.22 \\
\hline 3rd quartile & 24.08 & 5.10 & 47.00 & 80000 & 71000 & 97400 & 5.34 & 5.36 & 5.26 \\
\hline mean value & 18.66 & 7.07 & 29.21 & 81700 & 57200 & 112000 & 5.30 & 5.42 & 5.19 \\
\hline standard deviation & 27.23 & 13.48 & 31.90 & 189700 & 105000 & 250000 & 0.76 & 0.81 & 0.69 \\
\hline coeff. of variation & 1.46 & 1.91 & 1.09 & 2.32 & 1.84 & 2.28 & 0.14 & 0.15 & 0.13 \\
\hline
\end{tabular}




\begin{tabular}{|c|c|c|c|c|c|c|c|c|c|c|c|c|c|c|c|c|c|c|c|c|c|c|c|c|c|}
\hline Sample & $\begin{array}{l}\mathrm{T} \\
\left({ }^{\circ} \mathrm{C}\right) \\
\end{array}$ & pH & $\begin{array}{l}\text { cond@25 }{ }^{\circ} \mathrm{C} \\
\left(\mu \mathrm{S} . \mathrm{cm}^{-1}\right)\end{array}$ & $\begin{array}{l}\text { Eh } \\
(\mathrm{mV})\end{array}$ & $\begin{array}{l}\mathrm{Ca} \\
(\mathrm{mg} / \mathrm{l})\end{array}$ & $\begin{array}{l}\mathrm{Mg} \\
(\mathrm{mg} / \mathrm{l})\end{array}$ & $\begin{array}{l}\mathrm{Na} \\
(\mathrm{mg} / \mathrm{l})\end{array}$ & $\begin{array}{l}\mathrm{K} \\
(\mathrm{mg} / \mathrm{l})\end{array}$ & $\begin{array}{l}\mathrm{Fe}(\mathrm{III}) \\
(\mathrm{mg} / \mathrm{l})\end{array}$ & $\begin{array}{l}\mathrm{Mn} \\
(\mathrm{mg} / \mathrm{l})\end{array}$ & $\begin{array}{l}\mathrm{Sr} \\
(\mathrm{mg} / \mathrm{l})\end{array}$ & $\begin{array}{l}\mathrm{Li} \\
(\mathrm{mg} / \mathrm{l})\end{array}$ & $\begin{array}{l}\mathrm{HCO}_{3} \\
(\mathrm{mg} / \mathrm{l})\end{array}$ & $\begin{array}{l}\mathrm{Cl} \\
(\mathrm{mg} / \mathrm{l})\end{array}$ & $\begin{array}{l}\mathrm{SO}_{4} \\
(\mathrm{mg} / \mathrm{l})\end{array}$ & $\begin{array}{l}\mathrm{PO}_{4} \\
(\mathrm{mg} / \mathrm{l})\end{array}$ & $\begin{array}{l}\mathrm{NO}_{3} \\
(\mathrm{mg} / \mathrm{l})\end{array}$ & $\begin{array}{l}\mathrm{F} \\
(\mathrm{mg} / \mathrm{l})\end{array}$ & $\begin{array}{l}\mathrm{Br} \\
(\mathrm{mg} / \mathrm{l})\end{array}$ & $\begin{array}{l}\mathrm{SiO}_{2} \\
(\mathrm{mg} / \mathrm{l})\end{array}$ & $\begin{array}{l}\delta^{18} \mathrm{O} \\
(\% \text { VSMOW) }\end{array}$ & $\begin{array}{l}\delta D \\
(\% \text { VSMOW) }\end{array}$ & $\begin{array}{l}\text { theoretical } \delta D \\
\text { if belonging to } L M W L\end{array}$ & $\left.{ }^{87} \mathrm{Sr}\right|^{86} \mathrm{Sr}$ & $\begin{array}{l}{ }^{13} C_{\text {gas }} \\
\text { open sys. }\end{array}$ \\
\hline Chapelle 1 (2006) & 17.8 & 6.54 & 5210 & 338 & 237 & 121 & 776 & 81.9 & & & 3.74 & & 2288 & 717 & 146 & & 4.9 & & & & -8.3 & -57.4 & -53.3 & 0.712298 & -4.6 \\
\hline Chapelle 1 (2007) & 16.6 & 6.63 & 4530 & 391 & 248 & 137 & 875 & 97.4 & & & 4.37 & 4.48 & 2465 & 806 & 155 & & 2.8 & 0.7 & 1.8 & & & & & & -5.1 \\
\hline Chapelle 2 (2006) & 18 & 6.21 & 3070 & 336 & 196 & 117 & 304 & 34.5 & & & 2.5 & & 1276 & 298 & 192 & & 6.3 & & & & -7.5 & -53.7 & -46.9 & 0.712818 & -2.8 \\
\hline Chapelle 2 (2007) & 16.6 & 6.33 & 3130 & 444 & 188 & 127 & 360 & 39.1 & & & 2.38 & 1.66 & 1483 & 340 & 202 & & 4.4 & 0.9 & 0.7 & & & & & & -3.4 \\
\hline Chapelle 3 (2006) & 17.5 & 6.38 & 2730 & 340 & 178 & 104 & 266 & 34.6 & & 0.02 & 2.16 & & 1410 & 230 & 198 & & 8.3 & & & & -7.7 & -54 & -48.5 & 0.712035 & -3.7 \\
\hline Chapelle 3 (2007) & 15.9 & 6.51 & 2410 & 420 & 184 & 126 & 301 & 40.7 & & & 2.30 & 1.52 & 1332 & 315 & 209 & & 4.6 & 1.0 & 0.6 & & & & & & -4.5 \\
\hline Tennis (2006) & 29.2 & 6.48 & 7970 & 91 & 306 & 131 & 1493 & 163 & & 0.10 & 6.37 & & 3554 & 1495 & 101 & & & & & & -9.6 & -63.2 & -63.7 & 0.713388 & -3.9 \\
\hline Tennis (2007) & 29 & 6.46 & 7970 & 140 & 295 & 135 & 1486 & 167 & & & 6.66 & 8.03 & 3515 & 1348 & 129 & & & 0.5 & 3.7 & & & & & & -3.9 \\
\hline Tennis (2008) & 28.5 & 6.58 & 8440 & 138 & 301 & 133 & 1461 & 163 & 2.75 & & & & 3527 & 1370 & 111 & 0.4 & & 1.1 & & 107 & -9.5 & -62.8 & -62.9 & & -4.4 \\
\hline Geyser Brissac (2006) & 24.6 & 6.65 & 8180 & 186 & 307 & 133 & 1497 & 163 & & 0.10 & 6.33 & & 4135 & 1429 & 100 & & & & & & -9.6 & -63 & & 0.713387 & -4.9 \\
\hline Geyser Brissac (2007) & 23.5 & 6.62 & 7990 & 180 & 297 & 136 & 1485 & 167 & & & 6.88 & 7.99 & 3534 & 1355 & 126 & & & 0.4 & 3.7 & & & & & & -4.8 \\
\hline Geyser Brissac (2008) & 23 & 6.57 & 8310 & 158 & 299 & 132 & 1447 & 162 & 2.80 & & & & 3562 & 1360 & 111 & 0.5 & & 1.1 & & 106 & -9.5 & -62.7 & -62.9 & & -4.6 \\
\hline Petit Saladis (2007) & 21.6 & 6.58 & 8190 & 245 & 295 & 136 & 1498 & 168 & & & 6.29 & 8.13 & 3554 & 1344 & 125 & & & 0.5 & 3.5 & & & & & & -4.7 \\
\hline Grand Saladis (2007) & 16.1 & 7.24 & 7920 & 386 & 125 & 139 & 1579 & 180 & & & 2.60 & 8.52 & 3124 & 1414 & 108 & & 11.0 & 0.4 & 3.9 & & & & & & -7.6 \\
\hline old plant sp. (2008) & 29.3 & 6.7 & 8270 & 140 & 302 & 133 & 1457 & 164 & 2.41 & & & & 3147 & 1390 & 110 & 0.4 & & 0.8 & & 105 & -9.5 & -63 & -62.9 & & -4.9 \\
\hline Valois sp. (2008) & 25.3 & 6.45 & 7840 & 105 & 298 & 129 & 1461 & 163 & 2.80 & & & & 3536 & 1370 & 109 & 0.4 & & 1.2 & & 106 & -9.5 & -62.9 & -62.9 & & -3.9 \\
\hline terrace sp. (2008) & 18.6 & 6.45 & 8410 & 197 & 296 & 131 & 1459 & 163 & 2.44 & & & & 3566 & 1360 & 111 & 0.3 & & 1.2 & & 102 & -9.6 & -62.8 & -63.7 & & -4.1 \\
\hline rainwater (08/10/2008) & 12.4 & 8.45 & 65 & 273 & 4.2 & 0.9 & 8.3 & 1.2 & 0.03 & & & & 24 & 6 & 2 & & 1.7 & & & 0.7 & -8.8 & -64.7 & -57.3 & & -9.2 \\
\hline
\end{tabular}




\begin{tabular}{|c|c|c|c|c|c|}
\hline \multirow{2}{*}{$\begin{array}{l}\text { radon-222 }\left(\mathrm{Bq} \cdot \mathrm{m}^{-3}\right) \\
\text { DATA greater than } 10 \mathrm{~Bq} \cdot \mathrm{m}^{-3} \\
\text { and lesser than } 10^{6} \mathrm{~Bq} \cdot \mathrm{m}^{-3}\end{array}$} & \multirow{2}{*}{$\begin{array}{c}\text { POINT 2 } \\
06 / 10 / 08 \rightarrow 28 / 01 / 09\end{array}$} & \multicolumn{4}{|c|}{ POINT 4} \\
\hline & & $06 / 10 / 08 \rightarrow 28 / 01 / 09$ & $26 / 02 / 09 \rightarrow 01 / 09 / 09$ & $11 / 09 / 09 \rightarrow 16 / 03 / 10$ & $06 / 10 / 08 \rightarrow 16 / 03 / 10$ \\
\hline nb of meas. (hours) & 2728 & 2729 & 3869 & 740 & 7338 \\
\hline hours of deployment & 2735 & 2735 & 4471 & 4459 & 11665 \\
\hline Min. value & 60 & 30 & 50 & 1030 & 30 \\
\hline Max. value & $2.69 \mathrm{E}+05$ & $2.14 \mathrm{E}+05$ & $9.09 \mathrm{E}+05$ & $9.80 \mathrm{E}+05$ & $9.80 E+05$ \\
\hline 1st Quartile & 5820 & 20900 & 2410 & 5890 & 9640 \\
\hline Median value & 28500 & 51700 & 4810 & 7500 & 16800 \\
\hline 3rd Quartile & 102000 & 71500 & 13600 & 10700 & 12500 \\
\hline Mean value & 56500 & 65300 & 28700 & 26300 & 31300 \\
\hline std. dev. & 66400 & 57600 & 73600 & 93200 & 66100 \\
\hline PEAK values: $n b$ of meas. & 3 & 4 & 1 & & \\
\hline PEAK values: Max. value & 8.57E+07 & $7.06 \mathrm{E}+06$ & $1.24 \mathrm{E}+06$ & & \\
\hline Cycle analysis & no cycle & $\begin{array}{c}7-10-22 \text { hours } \\
5.5 \text { days }\end{array}$ & $15-25-39-74$ hours & 24 - 58 hours & \\
\hline
\end{tabular}




\begin{tabular}{|c|c|c|c|c|c|c|c|c|c|c|c|c|c|c|c|c|c|c|c|c|}
\hline \multirow{2}{*}{$\begin{array}{l}\text { DESCRIPTIVE } \\
\text { STATISTICS }\end{array}$} & \multicolumn{5}{|c|}{ day 1 (7400 data) } & \multicolumn{5}{|c|}{ day 2 (8300 data) } & \multicolumn{5}{|c|}{ day 3 (13800 data) } & \multicolumn{5}{|c|}{ day 4 (15800 data) } \\
\hline & $\mathbf{T}^{\circ}$ & EC & $\mathrm{O}_{2}$ & $\mathrm{pH}$ & Eh & $\mathrm{T}^{\circ}$ & $\mathrm{EC}$ & $\mathrm{O}_{2}$ & $\mathrm{pH}$ & Eh & $\mathbf{T}^{\circ}$ & $\mathrm{EC}$ & $\mathrm{O}_{2}$ & $\mathrm{pH}$ & Eh & $\mathrm{T}^{\circ}$ & $\mathrm{EC}$ & $\mathrm{O}_{2}$ & $\mathrm{pH}$ & Eh \\
\hline minimum & 21.15 & 8505 & 7.7 & 6.75 & 1.1 & 23.14 & 8512 & 7.9 & 6.74 & 31.6 & 21.98 & 7621 & 5.3 & 6.40 & -162.1 & 22.05 & 8477 & 5.9 & 6.43 & -61.4 \\
\hline maximum & 23.89 & 9184 & 10.8 & 6.80 & 29.7 & 23.88 & 8567 & 12.3 & 6.80 & 70.1 & 23.66 & 8264 & 18.0 & 7.28 & 206.2 & 23.00 & 8639 & 14.5 & 7.81 & 128.9 \\
\hline mean value & 23.62 & 8532 & 9.2 & 6.78 & 20.5 & 23.62 & 8537 & 9.7 & 6.78 & 54.2 & 22.54 & 8061 & 9.9 & 6.83 & 69.2 & 22.57 & 8535 & 9.2 & 6.84 & 57.7 \\
\hline standard deviation & 0.16 & 37 & 0.5 & 0.01 & 7.1 & 0.16 & 4 & 0.9 & 0.01 & 7.4 & 0.13 & 72 & 1.1 & 0.03 & 12.4 & 0.17 & 7 & 0.9 & 0.02 & 15.0 \\
\hline
\end{tabular}

